\title{
Why Plea-Bargaining Fails to Achieve Results in So Many Criminal Justice Systems: A New Framework for Assessment
}

Nuno Garoupa

ngaroup@gmu.edu

Frank H. Stephen

Follow this and additional works at: https://scholarship.law.tamu.edu/facscholar

Part of the Law Commons

\section{Recommended Citation}

Nuno Garoupa \& Frank H. Stephen, Why Plea-Bargaining Fails to Achieve Results in So Many Criminal Justice Systems: A New Framework for Assessment, 15 Maastricht J. Eur. \& Comp. L. 323 (2008). Available at: https://scholarship.law.tamu.edu/facscholar/482

This Article is brought to you for free and open access by Texas A\&M Law Scholarship. It has been accepted for inclusion in Faculty Scholarship by an authorized administrator of Texas A\&M Law Scholarship. For more information, please contact aretteen@law.tamu.edu. 


\title{
WHY PLEA-BARGAINING FAILS TO ACHIEVE RESULTS IN SO MANY CRIMINAL JUSTICE SYSTEMS: A NEW FRAMEWORK FOR ASSESSMENT*
}

\author{
Nuno Garoupa ${ }^{* *}$ and Frank H. Stephen ${ }^{* * *}$
}

\begin{abstract}
The myth of American exceptionalism in the matter of plea-bargaining is certainly by now quite untrue. In addition to forming an important part of criminal procedure in the United Kingdom, plea-bargaining has been transplanted to several civil law countries such as France and Italy. Informal versions, based on non-trial settlement, have been observed in Germany, Belgium, the Netherlands, and around the world. The Law and Economics literature on plea-bargaining views it as an efficient instrument of criminal procedure because it reduces enforcement costs (for both parties) and allows the prosecutor to concentrate on more meritorious cases. Yet the success of transplants relies on the existence of appropriate incentives, and the detailed study of the Italian experience provides a good indication that the traditional inquisitorial system might not generate such incentives. Instead, this article offers a new theory emphasizing the role of the prosecutor and that of the defence counsel. We argue that the incentives of the prosecutor and those of the defence counsellor are determinants of the success or failure of plea-bargaining. We are sceptical that plea-bargaining can lead to or is consistent with the desirable outcome in many circumstances. In particular, a major implication of our analysis is that the comparative
\end{abstract}

We are grateful to two anonymous referees, Oren Gazal-Ayal, Tom Ginsburg, Morag Goodwin, Jon Klick, Larry Ribstein, Limor Riza, Justice Robert Steigmann, Cyrus Tata and seminar participants at the law schools of Illinois, Chicago and Florida State Universities for helpful comments, and to Lydie Ancelot for excellent notes on the French system. Yeny C. Estrada has provided excellent research assistantship. The usual disclaimer applies.

* Professor of Law, University of Illinois College of Law; Research Professor, IMDEA (Madrid) \& Research Professor of Law, School of Law, The University of Manchester; ngaroupa@law.uiuc.edu.

*.* Professor of Regulation, School of Law, The University of Manchester; frank.stephen@manchester. ac.uk. 
efficiency of plea-bargaining to a larger extent depends on the possibility of a legal system to address the multiple principle-agent problems in criminal litigation.

Keywords: plea-bargaining; comparative criminal law; law and economics; prosecutor; defence counsel; judge

\section{$\$ 1 . \quad$ INTRODUCTION}

Plea-bargaining is very much a reality outside the United States. The myth of American exceptionalism in this matter is certainly by now quite untrue. It is now an important part of criminal procedure in the United Kingdom (with its three separate criminal law jurisdictions of England \& Wales, Scotland and Northern Ireland, all with somewhat different versions of plea-bargaining). Plea-bargaining has also been transplanted to several civil law countries (most notably France, Italy, Poland, and Argentina), despite the severe criticism from traditional doctrinal approaches, but apparently without major empirical success (either in widespread use or in cost reduction). ${ }^{1}$ Informal versions, based on non-trial settlement, have been observed in Germany, Belgium, the Netherlands, and around the world, again generating serious opposition. ${ }^{2}$

The reality is that $95 \%$ of all convictions in the US are secured with a guilty plea; guilty pleas are widely observed in the UK (more than $90 \%$ ); but only $8 \%$ of all convictions in Italy are obtained by plea-bargaining. ${ }^{3}$ It seems to us that these figures confirm the importance of plea-bargaining in criminal procedure. However, plea-bargaining is rarely used outside common law countries, where criminal procedure is adversarial in nature. Plea-bargaining is not frequently used in European civil law countries where criminal procedures are inquisitorial. ${ }^{4}$

While the discussion that has emerged as a result of the comparative observations presupposes the beneficial nature of transplants in criminal procedure, ${ }^{5}$ we prefer to see

1 See e.g., N. Boari, 'On the Efficiency of Penal Systems: Several Lessons from the Italian Experience', 17 Int. Rev. of L. and Ec. 115 (1997); N. Boari and G. Fiorentini, 'An Economic Analysis of Plea Bargaining: The Incentives of the Parties in a Mixed Penal System', 21 Int. Rev. of L. and Ec. 213 (2001) (For the Italian experience, patteggiamento). For the French case (plaider coupable), we are not aware of any empirical assessment so far.

2 It includes summary procedures for those who do not contest guilt; unconditional and conditional dismissals; confession of guilt for a reduction in the sentence, warnings and reprimands.

3 One should be careful in comparing numbers, since a conviction secured with a guilty plea does not necessarily imply the formal use of plea-bargaining. These numbers are discussed in Boari, 'On the Efficiency of Penal Systems: Several Lessons from the Italian Experience', and Boari and Fiorentini, 'An Economic Analysis of Plea Bargaining: The Incentives of the Parties in a Mixed Penal System'.

4 Obviously the lack of success in terms of use depends, in part, on how we define plea-bargaining. If we take a broader definition of plea-bargaining as any form of negotiated sentence that avoids criminal trial, then we might account for half or more of the convictions in many civil law countries.

5 See e.g., J. Herrmann, 'Bargaining Justice: A Bargain for German Criminal Justice', 53 University of Pittsburgh L. Rev. 755 (1992); H. Jung, 'Plea-Bargaining and its Repercussions on the Theory of 
Why Plea-Bargaining Fails to Achieve Results in so Many Criminal Justice Systems

it as an indication that the endorsement of plea-bargaining requires a broader assessment. The success of transplants relies on the existence of appropriate incentives, ${ }^{6}$ and the detailed study of the Italian experience provides a good indication that the traditional inquisitorial system might not generate such incentives. ${ }^{7}$ A similar conclusion can be drawn from the French system. ${ }^{8}$

The success of plea-bargaining in adversarial systems is also not so clear cut, unless we measure success by the rate of guilty pleas. In order to understand what we mean by success in the widespread use of plea-bargaining in the United States (as generally interpreted by legal economists), we first should realize that the American model of pleabargaining is quite complex and diverse. It is not a simple bargain between the accused and the prosecutor in order to settle for a given sentence in return for a guilty plea. ${ }^{9}$ In

Criminal Procedure', 5 Eur. J. of Crime, Criminal Law and Criminal Justice 112 (1997); E. Harnon, 'Plea-Bargaining in Israel - The Proper Functions of the Prosecution and the Court and the Role of Victims', 31 Israel L. Rev. 245 (1997); E. Grande, 'Italian Criminal Justice: Borrowing and Resistance', 48 Am. J. of Comp. L. 227 (2000); Y. Ma, 'Prosecutorial Discretion and Plea-Bargaining in the United States, France, Germany, and Italy: A Comparative Perspective', 12 Int. Criminal Justice Rev. 22 (2002); M. Langer, 'From Legal Transplants to Legal Translations: The Globalization of Plea-Bargaining and the Americanization Thesis in Criminal Procedure', 45 Harvard Int. L. J. 1 (2004); J. J. Jackson, 'The Effect of Human Rights on Criminal Evidentiary Processes: Towards Convergence, Divergence, or Realignment?', 68 Mod. L. Rev. 737 (2005).

6 See, N. Garoupa and A. Ogus, 'A Strategic Interpretation of Legal Transplants', 35 J. of Legal Studies 339 (2006) (for a general debate).

7 Boari, 'On the Efficiency of Penal Systems', and Boari and Fiorentini, 'An Economic Analysis of Plea Bargaining' identify several problems with the Italian experience. To start with, the objective of the transplant was to warrant a pre-trial settlement opportunity to reduce delays, not to enhance prosecutorial discretion as economists usually think. On the side of the prosecutor, they identify the following problems: lower concentration of resources because it is usually after the preliminary investigations have taken place; applies only to minor offences which do not justify an intensive use of resources; prosecutors advance their careers by seniority and not performance. On the side of the defendant, it applies to a limited group of defendants (minor offences), hence is less at ractive to accept; there are many acquittals for loss of evidence or witnesses and amnesties granted regularly; hence delays make it worthwhile to protract trials as long as possible to avoid jail.

8 The French plea-bargaining system has two stages: proposal and homologation. The prosecutor makes a proposal to the accused that can be in the form of a fine or an imprisonment sentence. However the deal must be reviewed by a judge, who can unilaterally reject it. The judge is intended to check the culpability of the accused in relation to the evidence, the recognition of guilt by the accused, and the legality and proportionality of the proposed sentence. If homologation fails, the prosecutor must continue the case. Plaider culpable is regulated by the Code de Procédure Pénale. Most of the echoed criticism in French legal writing against the introduction of this system addressed the procedural rights of the accused, the negative consequences of empowering the prosecution (the Ministère Public), and the incentives to avoid trial.

9 See Y. Kamisar et al., Modern Criminal Procedure: Cases-Comments-Questions (American Casebook Series, 12th ed. 2008). Furthermore, it varies across states. Plea-bargaining is a negotiated agreement between prosecution and defence in the federal system. In some states, such as New York and Illinois, bargaining is mostly with the judge, who imposes due process concerns. For example, in Longley $v$. State, 902 So. 2d 925 (Fla Dist. Ct. App. 5th Dist. 2005), the Court held that the defendant's right to due process was violated by the trial judge's involvement with initiating the plea-bargaining process. As a result, more and more states are hesitant to formally permit judges to become involved with the 
the United States, a plea bargain is an agreement between the state and the defendant, which is approved by the court. ${ }^{10}$ Generally, the transaction consists of the prosecutor making concessions, such as an agreement that the state will dismiss a second count against the defendant, in exchange for the defendant's concession to plead guilty or nolo contendere. ${ }^{11}$ However, in the United States the validity of a plea bargain must meet certain constitutional norms in addition to any local statutory requirements or rules of the court. ${ }^{12}$ It is the court's duty to insure that all the necessary elements of a valid guilty plea have been met. ${ }^{13}$

Overall, plea-bargaining is a contract-like negotiation embedded in a set of relationships involving other interests: the accused and his lawyer; the prosecutor assigned to the case and the prosecutorial body in general, $;{ }^{14}$ the victim and, potentially, her lawyer; the judge presiding over the case and the judiciary in general; third parties and society in general. Plea-bargaining is a particular contract within this complex nexus. In the language of new institutional economics, we could say that plea-bargaining is part of a complex nexus of contracts by very different players. ${ }^{15}$ It certainly requires a better understanding of the institutional environment before jumping to conclusions. ${ }^{16}$

Plea-bargaining has been the object of very serious criticism. It is highly controversial among legal scholars even in common law countries, including reputed law professors in the US and the UK. ${ }^{17}$ In that respect, the Law and Economics literature contrasts with many other legal approaches in its upbeat assessment. The most essential message of the vast economic literature on plea-bargaining is that it is an efficient instrument of criminal procedure because it reduces enforcement costs (for both parties) and allows the prosecutor to concentrate on more meritorious cases. ${ }^{18}$ Plea bargains are

initiation of the plea bargaining process. Currently, statutes or rules in several states expressly prohibit the trial judges from participating in plea negotiations, limiting their participation to the acceptance or rejection of the agreement negotiated by the prosecutor and the defence lawyer.

10 State v. Kennedy, 698 So.2d 349 (Fla. App. 4th Dist. 1997).

11 Benjamin v. State, 874 S.W.2d 132 (Tex. App.14th Dist. 1994).

12 D. J. Newman, 'Pleading Guilty for Consideration: A Study of Bargain Justice', 46 J. of Criminal Law, Criminology and Political Science 780 (1956).

13 Ibid.

14 For example, in England \& Wales, the Crown Prosecution Service.

15 Economists use contracts not in the legal sense, but for every kind of explicit and implicit agreement.

16 Some economists have already highlighted the institutional context as a necessary element in the evaluation of plea-bargaining. Compare F. Easterbrook, 'Criminal Procedure as a Market System', 12 J. of Legal Studies 289 (1983) (who goes in that direction but simply defends American criminal procedure as superior to the German model), with R. Adelstein and T. J. Miceli, "Toward a Comparative Economics of Plea Bargaining,' 11 Eur. J. of L. and Ec. 47 (2001) (another comparative view); contra M. Dubber, 'American Plea Bargains, German Lay Judges, and the Crisis of Criminal Procedure', 49 Stanford L. Rev. 547 (1996) (a contrasting view).

17 See the recent seminar on plea-bargaining (Fall 2007) published by 91 Marquette L. Rev. (2007).

18 Easterbrook, 'Criminal Procedure as a Market System' (the most optimistic paper). 
the criminal counterpart of civil out-of-court settlements that Law and Economics has largely supported. ${ }^{19}$

The present paper takes the view that there is a socially desirable (efficient) outcome for each criminal case. We are sceptical that plea-bargaining can lead to or is consistent with the desirable outcome in many circumstances. Therefore, our point is not to reject an efficiency assessment of plea-bargaining, or criminal procedure in general, but rather mitigate any general optimism about the result of such assessment.

In Section 2, we summarize the current Law and Economics of plea-bargaining. We review the multiple arguments that legal economists have developed to endorse the widespread use of plea-bargaining (including reduction of costs, reduction of uncertainty, and the use of a market-approach to the criminal justice system). Most of these arguments do not rely on any specific criminal justice system, and therefore fail to explain why plea-bargaining has largely failed in civil law jurisdictions.

In Section 3, we look at the usual arguments against plea-bargaining and identify two strands of the literature. First, we summarize arguments that in our view are not compelling from a comparative perspective. We then analyze those arguments that reflect the issues encountered with plea-bargaining in both common and civil law jurisdictions. Such powerful arguments have not convincingly been addressed by legal economists in our view.

In the fourth section, a more comprehensive framework to assess plea-bargaining from a comparative perspective is considered. Our new theory emphasizes the role of the prosecutor and that of the defence counsel. We argue that the incentives of the prosecutor and those of the defence counsellor are determinants of the success or failure of plea-bargaining. For example, on the defendant's side, the way a criminal legal aid system is implemented, or the way public defender offices are organized, explain many of the difficulties encountered by plea-bargaining in England \& Wales as well as in France or in Italy. On the prosecutor's side, the literature has been inspired by the American empowered prosecutor, yet the model is more complicated when one takes into account the serious institutional differences with other prosecutorial bodies, seen as weaker in England \& Wales and more bureaucratic in most civil law jurisdictions.

Our approach also encompasses two other important dimensions: third party effects and judicial scrutiny. Although the interests of the victims could play an important role in designing plea-bargaining rules, we are not convinced that empowering the victim with veto rights is a wise solution to the alleged gap between the goals of the prosecutor and the victim's welfare. Further, judicial scrutiny is a major cause of the observed differences between civil and common law jurisdictions. Our approach looks at the advantages and disadvantages of empowering judges with a more active role (such as they have in France or in Italy), and conclude with a cautions endorsement for intervention after plea-

19 See e.g., S. Shavell, Foundations of Economic Analysis of Law (Harvard University Press, 2004), chapters 17-19; T. Miceli, The Economic Approach to Law (Stanford University Press, 2004), chapter 8. 
bargaining. Quite clearly we reject the view endorsed by legal economists that judges should not be part of the plea-bargaining procedure, but we also find serious problems with models of judicial intervention before plea-bargaining is concluded.

The final section concludes our argument by stating that the failure of plea-bargaining in civil law jurisdictions shows that legal economists have neglected some important arguments with respect to the framework in which plea-bargaining operates.

\section{\$2. THE ECONOMICS OF PLEA-BARGAINING}

The field of law and economics is quite optimistic about the widespread use of pleabargaining. There are three fundamental lines of reasoning to justify the efficiency of plea-bargaining. First, entering a plea-bargain reduces costs and allows the prosecutor to allocate resources more effectively. ${ }^{20}$ Secondly, it maximizes social welfare because it reduces uncertainty (since the outcome of a criminal trial is not certain; notice, however, that when sentence benchmarking is applied this argument is qualitatively weak). Thirdly, it operates just like discretion in regulatory proceedings, ${ }^{21}$ hence the presence of a market-approach - which is largely believed to be a good idea - enhances the quality of the prosecution. ${ }^{22}$ Plea-bargaining thus enhances the quality of prosecution because it provides consistent signals that can improve prosecutorial decisions; it creates an efficient screening of cases; and therefore provides the adequate incentives for an efficient decision to stand trial. Finally, the use of plea-bargaining is consistent with the lowprobability high-penalty enforcement strategy proposed by economists (by imposing punishment infrequently). ${ }^{23}$

20 See Easterbrook, 'Criminal Procedure as a Market System'; G. M. Grossman and M. L. Katz, 'Plea Bargaining and Social Welfare', 73 Am. Ec. Rev, 749 (1983); C. Y. C. Chui, 'Plea Bargaining with the IRS,' 41 J. of Public Ec. 319 (1990).

21 See S. J. Schulhofer, 'Criminal Justice Discretion as a Regulatory System,' 17 J. of Legal Studies 43 (1988) (making the point that the criminal process is a regulatory process while plea-bargaining bypasses it and makes it less regulated).

22 See e.g., J. F. Reinganum, 'Plea Bargaining and Prosecutorial Discretion', 78 Am. Ec. Rev. 713 (1988); S. Baker and C. Mezzeti, 'Prosecutorial Resources, Plea-Bargaining, and the Decision to Go to Trial', $17 \mathrm{~J}$. of L., Ec. and Org. 149 (2001); R. Wright and M. Miller, 'The Screening/Bargaining Trade-Off, 55 Stanford L. Rev. 29 (2002); G. Lynch, 'Screening versus Plea Bargaining: Exactly what are We Trading Off?', 55 Stanford L. Rev. 1399 (2003); S. Bibas, 'Plea Bargaining Outside the Shadow of Trial,' 117 Harvard L. Rev. 2463 (2004); W. Stuntz, 'Plea Bargaining and Criminal Law's Disappearing Shadow', 117 Harvard L. Rev. 2548 (2004); S. Mongrain and J. Roberts, 'Plea Bargaining with Budgetary Constraints', U. Toronto mimeograph and SSRN, Working Paper (2004); D. Bjerk, 'On the Role of Plea Bargaining and the Distribution of Sentences in the Absence of Judicial System Frictions', 28 Int. Rev. of L. and Ec. 1 (2008) (although Easterbrook, 'Criminal Procedure as a Market System' already makes this point, there is an extensive literature on plea-bargaining and the quality of prosecution).

23 See A. M. Polinsky and S. Shavell, 'The Economic Theory of the Public Enforcement of the Law', 38 J. of Ec. Lit. 42 (2000) (for the general theory); See B. Kobayashi and J. Lott, 'Low-Probability-High-Penalty Enforcement Strategies and the Efficient Operation of the Plea-Bargaining System', 12 Int. Rev. of L. and Ec. 69 (1992) (for the precise relationship between plea-bargaining and efficient enforcement). 
We argue that the economic optimism for plea-bargaining arises from it being viewed as a counterpart of out-of-court settlements in civil procedure. Plea-bargaining is thus perceived as a contract between two parties, ${ }^{24}$ and, as such, should enhance social welfare if voluntarily performed. Due to the existence of an asymmetry of information concerning guilt and evidence, an appropriate design must be used to make the most of such a contract. If well designed, plea-bargaining helps prosecutors to acquire information and evidence.

The general reference to plea-bargaining by legal economists can be misleading and confusing since there are several types of bargains that can be loosely placed under such a designation (in fact, plea-bargaining is more of an umbrella term for different procedures). Instead, they can differ with respect to the content of the bargain (the scope of the contract-like negotiation), the point at which the bargaining occurs, and the mechanism by which it is achieved.

With respect to the scope of the bargaining, we should consider charge bargaining (multiple charges: drop some in return for a plea of guilty to one of them; unique charge: drop a serious charge in exchange for a plea of guilty to a less serious charge); fact bargaining (agreement for a selective presentation of facts in return for a plea of guilty); specific types of bargaining (nolo contendere pleas: accepts a sanction without pleading guilty; Alford pleas: accepts a sanction but defendant asserts innocence; parties negotiate and agree on charges and facts but leave the sanction to be determined by the court); and sentence bargaining (there is a specific discount for pleading guilty). ${ }^{25}$ Although the different types of bargaining result in different problems, ${ }^{26}$ we will also discuss pleabargaining in the general sense since the exact scope of the bargaining does not affect our approach. This is not the same as lumping together all the types of bargaining and arguing they are all the same. Whatever scope it has, legal economists see plea-bargaining as a contract-like negotiation that reduces expected costs for the accused. In that respect, the focus of our analysis is on the institutional set-up of the contract-like negotiation and not the exact scope of the bargaining. Obviously the problems we identify in this paper have different degrees of importance for each type of plea-bargaining.

In relation to the mechanism by which plea-bargaining is achieved, it can be explicit (a prosecutor makes a sentence recommendation or judges indicate the sentence they are minded to impose), implicit (a defendant pleads guilty, considering the existence of sentence discounts or the possibility of achieving a particular sentence, and without the need for real negotiation), or a simple negotiated diversion (warnings and reprimands in return for some restitution, transactions and conditional dismissals). It is quite

24 See R. E. Scott and W. J. Stuntz, 'Plea Bargaining as Contract,' 101 Yale L. J. 1909 (1992).

25 See A. Malani, 'Habeas Bargaining', 92 Virginia L. Rev. 1 (2006) (there is also habeas bargaining in the sense that the accused exchanges his habeas rights (i.e., the right to seek relief from unlawful detention) in return for shorter sentences much as they do with their trial rights in plea bargains).

26 See S. Bibas, 'Harmonizing Substantive-Criminal-Law Values and Criminal Procedure: The Case of Alford and Nolo Contendere Pleas', 88 Cornell L. Rev. 1425 (2003). 
important what effect these different mechanisms have on uncertainty and therefore the extent to which they generate different incentives for parties. Plea-bargaining is perceived by legal economists as a mechanism to reduce uncertainty for both sides; the source of uncertainty is usually the fact that the outcome of a trial is unknown. There are however two quite different interpretations. One possibility is that there is uncertainty concerning sentencing or with respect to the court finding the accused guilty and both parties have the same prior distribution of probabilities. Where this is the case, plea-bargaining is essentially assurance for both sides. Another possibility is that the parties have different perceptions. Then plea-bargaining is also a mechanism to reveal information concerning guilt and evidence. ${ }^{27}$

The timing of plea-bargaining is also important. Generally speaking, there is 'plea before venue' (the defendant has to decide whether or not to engage in plea-bargaining in early stages); in pre-trial hearings (the prosecutor and the defendant exchange information before bringing a plea bargain); during the trial hearings (including the possibility of a so-called cracked trial where the case is concluded without the last stage of trial due to a late or delayed guilty plea). As the possibility of a cracked trial increases, one of the economic arguments for plea-bargaining (reduction of costs to both sides) loses significance. On the other hand, plea-bargaining in the early stages of prosecution suffers from severe uncertainty and asymmetry of information that create quite serious agency problems. The balance is, thus, quite complicated. As times goes by, more information will become available (hence there will be a lower probability of mistakes) and cost savings go down. Therefore, there is an optimal timing for plea-bargaining. The problem is that the prosecutor and the accused may not have the same perception of timing. It is possible that costs have different profiles. Also, the availability of new information might depend on evidence rules and discovery. ${ }^{28}$ Certainly it seems likely that different crimes have different optimal timings, hence imposing a fixed framework for plea-bargaining across crimes could be counter-productive. It seems to us that the issue of timing (because of what type of information is available to the parties) has been underestimated by legal economists. ${ }^{29}$

Part of the explanation for the current system of plea-bargaining and its institutional framework can eventually be provided by legal historians. Unfortunately historical

27 Plea-bargaining can be seen as signalling or a screening game. When the prosecutor proposes an agreement to the accused, we have a screening game in that the prosecutor is attempting to separate out different types of accused. When the accused proposes an agreement to the prosecutor, it is a signalling game where the accused wants to signal to the prosecutor that he or she is of a certain type (e.g., guilty or innocent).

28 It is also clear that any discussion concerning plea-bargaining cannot be isolated from the rules of evidence and discovery in a given jurisdiction.

29 Contra L. Franzoni, 'Negotiated Enforcement and Credible Deterrence', 109 Economic Journal 509 (1999) (he develops a model of law enforcement in which indicted offenders and the prosecutor can negotiate the penalty prior to the completion of the investigation. The analysis focuses on the credibility of the conviction threat). 
justifications of plea-bargaining in the United States are unclear. ${ }^{30}$ Contrary to what is a widespread belief among legal economists, it might be that plea-bargaining had less to do with empowering the prosecution and bypassing jury trials (a similar argument has been made for the case of England \& Wales ${ }^{31}$ ), and more to do with finding a simple way to reduce the workload of courts in general and judges in particular; that is, it was an adaptation to caseload pressure (the difference with the reforms in Italy and France quite recently is that they were imposed by the legislator rather than being adaptation by the courts). ${ }^{32}$ Therefore, the empowerment of prosecutors could have been a nonintended consequence of plea-bargaining that legal economists have rationalized as a market mechanism to improve the quality of prosecution (which would be mitigated in inquisitorial systems anyway and possibly diluted by mandatory prosecution). ${ }^{33}$

30 See G. Fisher, Plea Bargaining's Triumph: A History of Plea Bargaining in America (Stanford University Press, 2003); M. Feeley, 'Legal Complexity and the Transformation of the Criminal Process: the Origins of Plea Bargaining', 31 Israel L. Rev. 183 (1997); G. Fisher, 'Plea Bargaining's Triumph', 109 Yale L. J. 857 (2000); B. P. Smith, 'Plea Bargaining and the Eclipse of the Jury', 1 An. Rev. of L. and Social Science 131 (2005). See also, M. Vogel, 'The Social Origins of Plea Bargaining: Conflict and the Law in the Process of State Formation, 1830-1860', 33 L. and Soc. Rev. 161 (1999) (arguing that the development of pleabargaining in the nineteenth century United States was as part of the nation building process).

31 In England \& Wales, an indication of a benchmark sentence by a judge is now possible by the Criminal Justice Act 2003; until recently there were some restrictive rules concerning the exchange of points of view between judge and defendant with respect to sentencing, the so-called Turner Rules, which delimited the judge's role in pre-trial procedures. See M. McConville and G. Wilson, The Handbook of the Criminal Justice Process (OUP, 2002), 353-377. Under $R v$ Turner [1970], the accused must only be advised to plead guilty if he has committed the crime in question; the judge should never indicate the sentence he has in mind if the accused were convicted after entering a plea of not guilty (but could say what sentence he would impose on a guilty plea). These rules were embodied in a Court of Appeal Practice Direction (1976). The problem of discussion in the judge's private room was addressed by $R v$ Pitman [1991]. The Runciman Royal Commission made important recommendations on more formalized plea-bargaining. After $R v$ Goodyear [2005], a judge dealing with a case may be asked by the accused to give, and if asked, is entitled to give an indication of the likely sentence, which should ordinarily be the maximum sentence he would impose on the accused if a plea of guilty were to be tendered at the stage at which the indication is sought. Obviously there are pre-trial hearings to facilitate exchange of information and bring about pleas of guilty, but it seems clear that judicial influence and control over criminal procedure is relatively reduced. See also, M. Zander, 'Please M'lud: How Long will I Get?', 155 New L. J. 677 (2005).

32 In England \& Wales, it was formally introduced under the 'plea before venue system' by the Criminal Procedure and Investigations Act 1996; although judicial precedent had created the one-third discount for guilty-pleas, this was incorporated into criminal law later by the Criminal Justice and Public Order Act 1994. The discount for pleading guilty was given legislative effect by taking into account (a) the stage of the proceedings at which the offender indicated his intention to plead guilty and (b) circumstances in which this indication was given. Subsequent controversy led to a set of Guidelines on the Acceptance Pleas by the Attorney-General in December 2000; now sentencing guidelines deal with pleas in detail (the recent Criminal Justice Act 2003).

33 The main point by Smith, 'Plea Bargaining and the Eclipse of the Jury', is that if plea-bargaining was one of several methods employed by common law administ rators to dispose of criminal cases without juries, then when compared with other modes to bypass trial by jury (e.g., bench trial), it is less distinctive and less American. 
A second line of reasoning would indicate that the choice of plea-bargaining (bypassing or avoiding but not eliminating jury trials) over bench trials in the United States in the nineteenth century and in England \& Wales quite recently was pushed by the need to reduce costs or delays (that is, secure benefits and avoid costs of criminal trials), hence raising the question of more effective alternative reforms in criminal procedure. ${ }^{34}$ Notice that such an observation would explain an apparently puzzling question, namely, why judges would agree with an instrument that clearly reduces their influence over the criminal justice system. ${ }^{35}$

Legal history might actually support the thesis that the introduction of plea-bargaining across jurisdictions might have happened for reasons that are not so dramatically different as is usually assumed. Also, viewing plea-bargaining as part of American criminal procedure without similarities across the world is simply misleading. Hence the nexus of relationships in which it is applied emerges as more important than relying on a specific historical explanation. For example, the standard explanation that the United States has legal proceedings dominated by lawyers whereas continental Europe is more dominated by bureaucrats seems to us to be pointing to what we have designated as the nexus of relationships rather than some precise historical distinction with respect to the influence of the legal profession.

Looking at the nexus of relationships in which plea-bargaining might emerge, legal economists have identified potential implementation problems. First, it is argued that pleabargaining reduces expected sanctions and hence it dilutes deterrence; to keep deterrence at current levels, plea-bargaining should be coupled with harsher sentencing. ${ }^{36}$ Secondly, it has been argued that increased sanctions and a differentiated use of plea-bargaining across crimes can lead to a substitution effect between different offences, resulting in more severe crime. ${ }^{37}$ Thirdly, one possible outcome from plea-bargaining is that of giving the lowest penalty to the most culpable defendant if it increases the probability of

34 P. Darbyshire, 'The Mischief of Plea-Bargaining and Sentencing Rewards', Criminal L. Rev. 895 (2000). See also, S. J. Schulhofer, 'Is Plea-Bargaining Inevitable?', 97 Harvard L. Rev. 1037 (1984).

35 The influence of judges is more adversely affected where the bargaining is exclusively conducted by the prosecutor and the defence. It is less of a problem when it is conducted, even if only partially or in limited circumstances, with judges, like the English sentence bargaining or plea-bargaining in many US jurisdictions. See L. Baum, 'What Judges Want: Judges' Goals and Judicial Behavior', 47 Political Research Quarterly 749 (1994), for why judicial support to plea-bargaining might reflect multiple goals.

See T. J. Miceli, 'Plea Bargaining and Deterrence: An Institutional Approach', 3 Eur. J. of L. and Ec. 249 (1996) (although such changes might not have the expected result). See also C. La Casse and A. Payne, 'Federal Sentencing Guidelines and Mandatory Minimum Sentences: Do Defendants Bargain in the Shadow of the Judge?', 42 J. of L. and Ec. 245 (1999); I. Kuziemko, 'Does the Threat of the Death Penalty Affect Plea Bargaining in Murder Cases? Evidence from New York's 1995 Reinstatement of Capital Punishment', 8 Am. L. and Ec. Rev. 116 (2006) (for an empirical assessment). 
Why Plea-Bargaining Fails to Achieve Results in so Many Criminal Justice Systems

conviction of conspirators; hence with multiple defendants, plea-bargaining should be subjected to special design. ${ }^{38}$

Another important argument that has been made calls attention to the fact that pleabargaining is determined by increasing trial costs and binding budgets, not social welfare. Hence, the efficiency depends on the objectives of prosecutors; clearly ex post objectives of prosecutors should determine ex ante criminal policies of legislator. Some scholars conclude that due to different prosecutorial objectives, plea-bargaining increases social welfare in adversarial but not in inquisitorial systems. ${ }^{39}$

The role of judicial scrutiny in plea-bargaining has also received attention in the literature. Initially the argument was against allowing judges to interfere with pleabargaining since prosecutors pursue the most meritorious cases and the quality of their work is improved. ${ }^{40}$ Current literature has discovered some advantages of allowing judges a more active role, namely improving the screening of cases between guilty and not guilty ${ }^{41}$ and enhancing the introduction of sentencing guidelines. ${ }^{42}$ Furthermore, judicial intervention avoids exceedingly lenient plea bargains. By hindering the prosecutor's ability to agree to exceedingly lenient sentences, courts increase the cost of handling weak cases without obstructing the prosecutor's ability to settle stronger cases.

As a summary, we can say that law and economics is quite positive about pleabargaining; it relies on a model of a mutually beneficial contract; prosecutorial discretion is perceived as being efficient (hence broadly more adequate to common law jurisdictions than continental Europe); it tends to downplay the role of judges. However, as we discuss below, this view neglects potential agency problems on both sides of the contract-like negotiation as well as third party effects.

\section{\$3. TRADITIONAL ARGUMENTS AGAINST PLEA-BARGAINING}

The arguments against plea-bargaining have been made systematically by scholars in criminal law in the US and in Europe. ${ }^{43}$ The simplest summary would be that plea-

See B. Kobayashi, 'Deterrence with Multiple Defendants: An Explanation for Unfair Plea Bargains,' 23 Rand J. of Economics 507 (1992).

39 See Adelstein and Miceli, 'Toward a Comparative Economics of Plea Bargaining'.

40 See Easterbrook, 'Criminal Procedure as a Market System'.

41 See O. Gazal-Ayal, 'Screening, Plea Bargains and the Innocent Problem', University of Michigan Legal Working Paper Series (2005).

42 See J. F. Reinganum, 'Sentencing Guidelines, Judicial Discretion and Plea Bargaining', 31 Rand J. of Economics 62 (2000).

43 See e.g. A. W. Alschuler, 'The Prosecutor's Role in Plea Bargaining', 36 Uni. of Chicago L. Rev. 50 (1968); A. W. Alschuler, 'The Defense Lawyer's Role in Plea-Bargaining', 84 Yale L. J. 1179 (1975); A. W. Alschuler, 'The Trial Judge's Role in Plea Bargaining', 76 Columbia L. Rev. 1059 (1976); A. W. Alschuler, 'The Changing Plea Bargaining Debate', 69 California L. Rev. 652 (1981); A. W. Alschuler, 'Implementing the Criminal Defendant's Right to Trial', 50 Uni. of Chicago L. Rev. 93 (1983). See also D. D. Guidorizzi, 
bargaining is a disaster in criminal procedure. ${ }^{44}$ Some of the arguments are somewhat philosophical, such as criminals receive undeserved leniency (this implies that the social costs of imposing sanctions should be neglected and assumes that the probability of conviction at trial is one $)^{45}$ or that plea-bargaining undermines procedural guarantees for the accused, thus becoming an important constitutional issue ${ }^{46}$ (hence requiring that all these rights and privileges cannot be derogated from even when the defendant wishes it so).

A discount for pleading guilty, under whatever process the specific bargain is made, imposes a penalty or a price on the right to be tried (the so-called trial tax). Scholars argue that it undermines the presumption of innocence by penalizing those who exercise their right to a trial and induces self-incrimination. ${ }^{47}$ However, as long as plea-bargaining is a voluntary contract it should not be a problem since those who go to court expect a higher payoff. After all that is why they reject the sugared guilty plea. A completely different issue is if the accused is coerced in one way or the other, thus taking a decision with a lower expected payoff. In such a situation, they are penalized because plea-bargaining is no longer mutually beneficial. This is an issue of unfair bargains which we discuss below.

Other arguments are more significant in our view; plea-bargaining hurts the innocent and gives rise to unfair bargains in content and in time. Hurting the wrongly accused has been the subject of attention by economists. Usually the argument means that the strategic selection of cases to go to trial has two implications: (i) those who are innocent (of the specific charge brought) stand trial more frequently than the guilty; (ii) there is pressure for the innocent to plead guilty. Nevertheless, from an economic perspective, those are not the most relevant questions. The issue is whether the introduction of pleabargaining affects the innocent in a disproportional way (in the statistical sense) from its effect on the guilty. The conviction of an innocent at trial is possible (there are wrongful convictions). In other words, unless plea-bargaining is disproportionately biased against the innocent than against the guilty, what harms those who are innocent is a set of rules

'Should We Really Ban Plea Bargaining? The Core Concerns of Plea Bargaining Critics', 47 Emory L. J. 753 (1998) (a good summary).

44 See S. J. Schulhofer, 'Plea Bargaining as Disaster', 101 Yale L. J. 1979 (1992). See also R. E. Scott and W. J. Stuntz, 'A Reply: Imperfect Bargains, Imperfect Trials, and Innocent Defendants', 101 Yale L. J. 2011 (1992).

45 See R. Christopher, 'The Prosecutor's Dilemma: Bargains and Punishments', 72 Fordham L. Rev. 93 (2003) (this is obviously a retributivist argument whereas an economic approach is consequentalist). See A. Ashworth and M. Redmayne, The Criminal Process (OUP, 3rd ed. 2005), chapter 12 (The availability of the not guilty plea is regarded as a guarantee of certain defendants' rights, namely the presumption of innocence; the right to examine witnesses against the accused; the right to a fair and public hearing. It is therefore controversial as to whether plea-bargaining can be compatible with the European Convention on Human Rights). Mod. L. Rev. 515 (1999). 
of evidence that unfortunately do not allow a perfect separating equilibrium between guilty and innocent. 48

As long as the probability of conviction is positively correlated with the probability of guilt, the selection-of-cases effect must imply a reduced proportion of innocent defendants. ${ }^{49}$ The reason is that prosecutorial discretion is not unconstrained. Hence, even if there is an incentive to offer a plea to low probability convictions, prosecutors have to (i) select cases under a fixed budget; (ii) cannot offer unlimited sentence discounts; and (iii) cannot control extra legal sanctions triggered by guilty pleas. Therefore, pleabargaining is more likely to prevail where the accused are guilty.

Since the economic approach is based on a contractual view of plea-bargaining, we find the argument against plea-bargaining based on unfair contracts to be of importance. ${ }^{50}$ It is difficult to have a precise notion of unfair contract, but we interpret the point raised by several scholars as meaning that sometimes one of the parties - normally the defendant - will accept a contract that is not in his own best interests ${ }^{51}$ (that is, the expected payoff from acceptance is less than that from going to trial). Within a rational theory framework, we need a complex model to justify such a possibility ${ }^{52}$ and assess the implications. ${ }^{53}$

Some scholars have argued that plea bargains are not civil settlements because civil litigants care only about (i) strength of evidence and (ii) expected punishment after trial. These scholars argue that there are important factors such as psychological bias and

48 See e.g. O. Bar-Gill and O. Gazal-Ayal, 'Plea Bargains Only for the Guilty', 49 J. of L. and Ec. 353 (2006); D. Bjerk, 'Guilt Shall Not Escape or Innocence Suffer? The Limits of Plea-Bargain when Defendant Guilt is Uncertain', 9 Am. L. and Ec. Rev. 305 (2007). Contra B. Kobayashi and J. Lott, 'In Defense of Criminal Defense Expenditures and Plea Bargaining', 16 Int. Rev. of L. and Ec. 397 (1996) (on the other hand, criminal defence expenditures result in lower than expected penalties for the innocent at trial in comparison to those found guilty, and they help ensure that plea-bargaining efficiently screens defendants).

49 Plea bargains allow prosecutors to charge more defendants and hence the number of defendants (guilty and innocent) is likely to increase. The proportion of innocents might decrease under certain conditions.

50 See Bibas, 'Plea Bargaining Outside the Shadow of Trial,' (for a general overview). See T. W. Church, 'In Defence of Bargain Justice', 13 L. and Soc. Rev. 509 (1979) (for a defence).

51 Whatever the definition one might have of a defendant's interests in this context, including emotional attrition, personal and family circumstances, aversion to being held in custody, etc.

52 Notice that it is quite distinct from a harsh contract. See A. Stein and U. Segal, 'A mbiguity Aversion and the Criminal Process', 81 Notre Dame L. Rev. 101 (2006) (making the point that defendants are in a very weak position because they face more ambiguity (i.e., more uncertainty concerning the probability of conviction) than the prosecutor, who is an experienced player. Although the argument neglects the role of the defence lawyer, who is also an experienced player, it points to harsh but not unfair agreements since the accused have more to lose than the prosecutor from a negotiation failure). See also $\mathrm{A}$. Tor, $\mathrm{O}$. Gazal-Ayal, and S. Garcia, 'Substantive Fairness and Comparative Evaluation in Plea Bargain Decision Making,' Haifa University Working Paper (2006) (tries to incorporate notions on fairness in assessing plea-bargaining outcomes).

53 Yet another source of a harsh contract could be the fact that whereas the accused has a non-exclusive right over the time of the prosecutor, the prosecutor has a monopoly right over the future of the accused. Therefore, one party has more power than the other in the bargaining process. Judicial scrutiny reduces that monopoly power. 
structural forces (the quality of the defence lawyer, hence the wealthy will be favoured), agency costs, bail and detention, legal rules, sentencing guidelines and statutes) that produce skewed bargains and hence unfair contracts. ${ }^{54}$

A second line of reasoning points out that plea-bargaining cannot be seen as the formation of voluntary contracts because the affected parties lack the incentive to assure public interest in effective law enforcement (third-party effects) and deny defendants a bargaining position to guarantee fair exchange. In particular, prosecutors face pressure for convictions and plea-bargaining is a mechanism to get them at the expense of procedural guarantees. There might be overcharging in order to increase pressure for a guilty plea.

These criticisms go in the direction of underlining the weak position of the defendant and the strong role of the prosecutor. ${ }^{55}$ We think that an overcharging effect cannot be so dramatic because there are two signals concerning guilt (one for the prosecutor and another for the jury and the judge), and both are correlated. Hence, the result must depend very much on the rules of discovery and evidence as well as on the ability of the defendant's lawyer.

The view of the present authors is that most of the criticisms described hint at the idea that plea-bargaining cannot be perceived as involving a simple contract in the way that an out-of-court settlement is treated in civil law. The weak position of the defendant is in many cases the result of an inefficient contract between the defendant and his lawyer, a point neglected in most of the literature. The role of the prosecutor is determined by institutional aspects that determine the nature of the relationship between the prosecutor and the rest of society. Aspects such as the adversarial versus inquisitorial nature of criminal procedure; mandatory versus selective prosecution; judicial scrutiny of prosecutorial decisions; the role of prosecutorial guidelines; the existence of prosecutorial proposed sentencing and judicial pre-commitment to sentencing, all necessarily tailor the way prosecutors engage in plea-bargaining, and these aspects vary widely across jurisdictions. ${ }^{56}$

54 See Bibas, 'Plea Bargaining Outside the Shadow of Trial'. Prosecutor, the Defense Counsel, and the Judge,' 16 Brigham Young Uni. J. of Public L. 189 (2002); M. Langer, 'Rethinking Plea Bargaining: The Practice and Reform of Prosecutorial Adjudication in American Criminal Procedure,' 33 Am. J. of Criminal L. 223 (2006). 


\section{\$4. A NEW THEORY OF PLEA-BARGAINING WITH IMPLICATIONS FOR COMPARATIVE LAW}

In this paper we provide a more comprehensive approach to plea-bargaining that addresses the problems we have identified above. We take plea-bargaining to be a voluntary contract between two parties (the prosecutor and usually the defendant's lawyer) inserted in a more general nexus of relationships that influence criminal procedure. It is a contract that takes place in a context of uncertainty and asymmetry of information; hence problems of moral hazard and adverse selection are likely to occur. It is also a contract between only two of the parties affected by it. Even if the terms of such a contract satisfied the parties directly involved, it may not maximize social welfare because of the negative consequences on others. It does not therefore guarantee a socially optimal bargain.

A usual argument against plea-bargaining is that it reduces the opportunity for improvement of the criminal justice system in terms of identifying the shortcomings of the law and of procedure, assessing the work of the police, exposing the ability of prosecutors, and lack of quality of defence lawyers. It decreases pressure for legal reform and undermines information to assure general deterrence due to it usually not being disclosed to the public. Although we recognize and discuss these third-party effects (in the sense that a settlement produces a negative externality on the quality of the legal system), they also apply to out-of-court settlements in civil law, and therefore do not constitute a distinct element of the discussion of plea-bargaining (although it is conceivable that the magnitude of the negative externality is more significant in criminal than in civil law, the reasoning is not substantially different and has been addressed in the literature). ${ }^{57}$

In our view, the striking difference between out-of-court settlements in civil and in criminal procedure is that the magnitude of agency costs is much higher in the latter than in the former. For reasons we discuss below, incentives between each side and respective legal representative are likely to be better aligned in civil rather than in criminal litigation. Moreover, third party effects are more important in criminal than in civil litigation because an effect on third parties differentiates an offence as criminal and not a tort. ${ }^{58}$

57 Compare the classical O. Fiss, 'Against Settlements', 93 Yale L. J. 1073 (1984), with S. Shavell, 'The Fundamental Divergence between the Private and the Social Motive to Use the Legal System,' 26 J. of Legal Studies 575 (1997).

58 See R. Bowles, M. Faure and N. Garoupa, 'The Scope of Criminal Law and Criminal Sanctions: An Economic Analysis and Policy Implications', 35 J. of L. and Society 389 (2008). 


\section{A. SCOPE OF PLEA-BARGAINING}

Asymmetry of information is important in assessing the efficiency of plea-bargaining. If information were symmetric and perfect, we would expect plea-bargaining to generate contract-like negotiations that would be efficient since agency costs would be zero. It is important to realize that it is not the scope of plea-bargaining (how much parties can negotiate) that increases the likelihood of inefficiency, but the existence of asymmetric information that makes an efficient contract harder to obtain. Therefore, the reasoning should be that we require instruments to reduce asymmetry of information rather than the scope of plea-bargaining.

There are three important elements to the reduction of asymmetry of information: sentencing benchmarks, rules of evidence and discovery, and timing. Sentencing benchmarks reduce divergent expectations concerning the outcome of a trial. Penal codes and sentencing guidelines favour this process, as do rules that impose on the prosecution a duty to announce a target sentence or a general principle of sentencing proportionality. Judicial discretion in this particular case has a twofold role. By making trials more uncertain, it induces parties to be more willing to engage in plea-bargaining. ${ }^{59}$ Therefore, by reducing the possibility of knowing sentencing benchmarks, it increases the possibility of inefficient contracts.

Rules of evidence are also relevant to reducing asymmetry of information. Mandatory disclosure for both parties before plea-bargaining and failure to disclose as justification for breach should be understood as mechanisms that favour efficient plea-bargaining. ${ }^{60}$ The strategic use of information and evidence will only increase the possibility that one of the parties will agree to plea-bargaining when they should not. ${ }^{61}$

59 We implicitly assume here that risk aversion predominates. However, the effects of uncertainty might be more complex. For example, self-serving bias and over-optimism might prevail when sentences are less certain, and reduce the willingness to engage in plea-bargaining. Also, when the trial result is uncertain, the prosecutor and the defence might have too different estimations over the sentence to make a settlement easy.

60 We do not take the view that forced full disclosure of evidence to reduce asymmetry of information is an absolute value; rather it must be balanced against constitutional principles and should not lead to self-incrimination. Our point is simply that many disclosure rules can be understood as promoting a reduction of asymmetry of information.

61 In the United States, evidence obtained through the plea-bargain negotiation cannot be used against the defendant in trial. Usually, any information gathered through the plea bargain remains off the record unless the prosecutors are able to open independent evidence to prove such information, which requires more time and money for the prosecution to investigate. The following cases support this argument: Wilson $v$ State, 484 S.W.2d 82 (1972); Hineman v State, 292 N.E.2d 618 (1973); Robinson v State, 644 P.2d 514 (1982); Dykes $v$ State, 372 S.W.2d 184 (1963) (various states hold that communications made in the course of plea bargaining are not admissible into evidence). Also Federal Rules of Evidence, Rule 410 \& Federal Rules of Criminal Procedure, Rule 11(e)(6) (the Federal Rules of Evidence and the Federal Rules of Criminal Procedure state that, subject to certain limited exceptions, any statement made in the course of plea discussions with an lawyer for the prosecuting authority which do not result in a plea of guilty or which result in a plea of guilty later withdrawn is not admissible as evidence against a participant in the plea discussions). 
The relevant rules of evidence and sentencing benchmarks (which are only possible after evidence is known) should determine the optimal timing of plea-bargaining. The earlier it takes place, the more enforcement costs are saved, but the higher are the chances that an inefficient contract is accepted. The later it takes place (cracked trials), fewer costs are actually saved, but given that almost all information has been revealed, the chances of an inefficient contract are quite low. There is a trade-off between cost saving and the quality of the plea-bargaining contract. Obviously the appropriate timing is determined by the nature of the crime and enforcement technology. When most of the evidence is actually gathered by the police and there are few actions taken by the prosecutors (which is loosely speaking the system in England \& Wales where the main goal seems to be the review of the police evidence to avoid hindsight bias rather than more detailed or goaloriented investigation as in the American system), plea-bargaining should take place earlier since not much evidence will be produced after the police investigation. When most of the evidence is produced during trial, then plea-bargaining should take place at later stages, an argument with significant implications for France and Italy.

\section{B. INFORMAL VERSUS FORMAL PLEA-BARGAINING}

Taking the view of plea-bargaining as any kind of out-of-court settlement between the prosecution and the defence that avoids a trial raises immediate questions concerning the informal versus formal nature of these procedures. The advantages of a formal system of plea-bargaining are transparency and the availability of information (hence the less serious asymmetries of information usually associated with secrecy) not only for the accused, but also for the victims and for the community in general, offering better accountability of prosecutors and defence counsellors. Part of this improved accountability can be achieved by an appropriate design of procedural rules that can only be implemented in a formal plea-bargain. Finally, if we are to subject plea-bargaining to judicial review we require a formal mechanism. ${ }^{62}$

There are three main disadvantages with formal mechanisms. One is that they are usually more costly than informal negotiations. A second disadvantage is that the parties are under the pressure of third parties (victims, judges, public opinion) that might limit the ability of prosecutors to strike an effective deal in some circumstances. The last disadvantage has to do with the need formally to enter a guilty-plea, which means that if the bargain is later rejected by the judge, the accused could be in trouble if a change of

62 Our understanding is that any agreement subject to judicial review is a formal plea-bargain. In the United States, no plea-bargain, either formally or informally negotiated, can be entered without a judge signing off on it, so in that respect we consider both forms of 'formal plea-bargaining'. Third party pressure will be present no matter if the negotiation was done informally or formally since they will be made public after the judge approves of it. So third party scrutiny will always be present in formal or informal negotiations since the 'people' are a party to the case in criminal law. 
plea is not allowed. ${ }^{63}$ In an informal plea-bargain, if the judge rejects the deal, the losses for the accused are less serious since no formal guilty-plea has been entered.

In our view, an informal mechanism can only be superior if agency costs on the defence side, as well as on the prosecutor's side, are relatively unimportant. The reasoning is that an informal mechanism is essentially based on the interaction between the prosecutor and the defence side without the interference of third parties. However, if agency costs are substantial and third party interference is required, a formal mechanism seems more appropriate.

The main conclusion from these considerations must be that one cannot separate the use of plea-bargaining from the rules of criminal procedure and criminal law in general. The balance between the benefits of saving trial costs and the costs of an inefficient contract is crucially determined by criminal law. Naturally, different rules and laws can but only generate a different optimal response to the balance of costs and benefits. However, criminal law might also shape, in a determinant way, the incentives for prosecutors and defendants, as we discuss in the following subsections.

\section{THE DEFENDANT'S PERSPECTIVE}

The economic theory of plea-bargaining treats the defendant's side in a very simple way: the defendant accepts the contract proposed by the prosecutor as long as the expected payoff it provides is higher than the best alternative (e.g., go to trial). The most important problem is that such a decision is usually taken by the defendant's lawyer (even if this is not formally the case, it will be very much influenced by her). Therefore, the defendant's side is affected also by a contract between these two parties, the accused and the lawyer. If such a contract is good enough to perfectly align the interests of both sides, then there are no agency costs (notice here that the principal is the defendant and the agent is the defence lawyer). In tort litigation, the usual solution is to implement contingent fees or some modified fee version (such as the British conditional fees). ${ }^{64}$ Such contracts

63 According to P. Hungerford-Welch, Criminal Litigation and Sentencing (Cavendish Publishing, $6^{\text {th }}$ ed. 2004), in England and Wales, a change from not guilty to guilty is possible at any stage before the verdict is given. However, a change from guilty to not guilty is at the discretion of the judge, and the defendant must offer a reason for his change of mind $(R v$ Sheikh [2004]). In the United States, it is discretionary for the court to permit or deny the withdrawal of a plea of not guilty to allow a guilty plea to be entered (see Douglas v. State, 663 N.E.2d 1153 (Ind. 1996)); for a withdrawal of a defendant's guilty plea before sentencing, the defendant has the initial burden of proving good cause or a fair and just reason for withdrawing the guilty plea by a preponderance of the evidence. If the defendant establishes sufficient grounds to warrant withdrawal, the burden shifts to the state to prove that it will be substantially prejudiced by withdrawal of the plea. A defendant may also withdraw his guilty plea after sentencing if he has shown 'a manifest injustice', i.e. if new material evidence was discovered after sentencing. Social Sciences 35 (2005) (an excellent survey on the economics of tort litigation). See W. Emons and N. Garoupa, 'US-style Contingent and UK-style Conditional Fees: Agency Problems and the Supply of Legal Services', 27 Managerial and Decision Economics 379 (2006) (with respect to the economics of 
function to align the interests of the client and lawyer. However, such a practice is hardly ever observed in criminal litigation, being in fact forbidden in many jurisdictions (not least because a substantive transference of financial resources is usually not involved in criminal litigation). ${ }^{65}$ Moreover, it is known that a very large proportion of defendants are relatively poor (hence most are found to be judgment-proof). We expect agency costs to be quite substantial, either because many defendants are on legal aid or defended by a public defender or because they lack the necessary wealth to design a contract that aligns incentives. When there are serious agency costs it is possible that contracts are inefficient, that is, a certain contract should be rejected by the defendant, but is accepted by the defendant's lawyer (even when the settlement's authority is formally assigned to the defendant, the decision will nevertheless be based on the advice and on the information provided by the counsellor who is supposed to act in the client's best interest but does not necessarily do so). ${ }^{66}$

Our reasoning thus moves the analysis in a new direction. In order to assess pleabargaining, we need to understand the role of the defendant's lawyer in criminal cases. ${ }^{67}$

contingent fees). See also R. Iyengar, 'Not Getting Their Due Process: An Evaluation of Federal Indigent Defense Counsel', ALEA 2006 conference paper, available at http://law.bepress.com/cgi/viewcontent. cgi? article=1681\&context=alea. But see M. McConville et al., 'Standing Accused: The Organization and Practices of Criminal Defence Lawyers in Britain,' in Oxford Monographs on Criminal Law and Justice (OUP, 1994) (with respect to the practice in the United Kingdom).

65 For example, even in the United States, contingent fee agreements between defendants and their lawyers are proscribed as unethical in criminal cases, and expressly forbidden by the American Bar Association Model Rules of Professional Conduct. See e.g., Lewin v. Law Offices of Godfrey G. Brown, 8 Misc. 3d 622,798 N.Y.S2d 884 (N.Y. City Civ. Ct. 2005) (stating that a lawyer may not enter into an arrangement for, charge, or collect a contingency fee for representing a defendant in a criminal case); American Bar Association Model Rules of Professional Conduct Rule 1.5 (d)(2)).

66 See Easterbrook, 'Criminal Procedure as a Market System', 309 (argues that the agency problem, while pervasive, is trivial because of reputation effects and is no different at any stage of criminal procedure). We do not find this argument persuasive. In particular, as demonstrated below, a fixed payment system increases the benefit to the lawyer of an early settlement. The confidential nature of the plea bargain discussion and the lack of information to accused persons render the reputation effect implausible. As we argue below different remuneration systems for defence lawyers have different implications for the intensity of this agency problem. In any case, a plea bargain can be presented to the accused as being a better result than going to trial, even when it is not. Ibid., 310 (Easterbrook also argues that those benefiting from publicly financed defence benefit more from a negotiated plea than those paying for their own defence). Again this will depend on the nature of the remuneration system of the publicly funded defender. Easterbrook appeals to a model of plea bargaining contained in an Appendix to the paper. However, this model abstracts from the very agency problem that is the focus of our discussion because bargaining is not just between the prosecutor and the defendant as implied by the model, thus ignoring the role of the defendant's lawyer.

67 With the notable exception of the UK literature on legal aid, we have not found any previous work on this matter in economics. Most economic models treat the defendant's lawyer as the perfect agent of the accused. See H. Gravelle and N. Garoupa, 'Optimal Deterrence with Legal Defense Expenditure', 40 Economic Inquiry 366 (2002). The role of the defence lawyer does feature in the literature on the legal aid expenditure in the United Kingdom. See e.g. A. Gray, P. Fenn, and N. Rickman, 'Controlling Lawyers' Costs through Standard Fees: An Economic Analysis', in Access to Criminal Justice (Blackstone Press, 1996); A. Gray, P. Fenn and N. Rickman, 'An Empirical Analysis of Standard Fees in Magistrates' Court 
In particular, the remuneration scheme has an important influence. If lawyers are not paid for the effort exerted to represent and defend their clients, we might have a problem of moral hazard (shirking) and adverse selection (bad lawyers, at least from a market perspective, are matched with poor defendants). Both effects will in turn lead to situations where the lawyer wants to get as many cases as possible in order to make more money and spend as little time as possible on each case. ${ }^{68}$ Plea-bargaining is an obvious way to achieve such objectives.

Therefore plea-bargaining could be highly inefficient not necessarily because out-ofcourt settlements are bad in criminal law, but because there are substantial agency costs incurred by one of the two sides of the contract-like negotiation. It seems to us that the introduction and development of plea-bargaining cannot be dissociated from the reform of the defendant's legal representation (unfortunately governments tend to leave legal aid out of the picture when they are reforming criminal law and procedure). As the judgment-proof nature of the defendant is the main origin of agency costs, legal aid is a fundamental piece of the puzzle.

Pro-bono representation lacks the necessary incentives for lawyers to exert effort (though we concede that intrinsic motivation could play an important role in mitigating this problem) and, even if mandatory as in some jurisdictions, there are adverse selection problems (experienced and high quality lawyers will subcontract to inexperienced and young lawyers who end up doing most of the work, thus providing such defendants with inexperienced, and sometimes low quality, legal representation).

We turn now to the different means by which publicly-funded representation may be provided to accused persons facing criminal charges. Although certain financial criteria may need to be met in order for the accused to qualify for legal aid, we abstract from that issue to concentrate on the differential effects of the different mechanisms for providing defendants with legal services, taking a closer look at the impact the different mechanisms will have on the magnitude and nature of the agency problem between the accused and his defence lawyer. Following on from this theoretical discussion, we draw on a number of empirical studies for further enlightenment.

Criminal Cases', Lord Chancellor's Department Research Paper $5 / 99$ (1999); F. H. Stephen, 'Reform of Legal Aid in Scotland', 8 Hume Papers on Public Policy 23 (2001); F. H. Stephen and C. Tata, 'Impact of the Introduction of Fixed Payments into Summary Legal Aid: Report of an Independent Study', Scottish Executive Justice Department (2006); P. Fenn, N. Rickman and A. Gray, 'Standard Fees for Legal Aid: Empirical Analysis of Incentives', 59 Oxford Economic Papers 662 (2007); F. H. Stephen, G. Fazio and C. Tata, 'Incentives, Criminal Defence Lawyers and Plea Bargaining,' 28 Int. Rev. of L. and Ec. 212 (2008).

68 The significance of this has been brought home by the findings of recent research on the impact of changing the remuneration contract of defence lawyers in the Scottish legal aid system from one of payment for work done to a fixed payment per case. See e.g. Stephen and Tata, ibid;; and Stephen, Fazio and Tata, ibid. 


\section{Legally-Aided Private Defenders}

In a number of jurisdictions publicly-funded defence services are provided through a system of outsourcing ${ }^{69}$ to independent firms of lawyers. The agency problems that arise in such a system depend on the nature of the remuneration system by which the lawyers are paid for this work. It should be noted that such systems of legal aid involve multiple agency relationships. In addition to the agency relationship between the accused person and his lawyer, there is also one involving the lawyer and those providing payment. The agency problems are in fact inter-related. Mechanisms designed to reduce the magnitude of one set of agency costs may result in an increase of agency costs in another interrelated agency relationship. In particular, remuneration systems for defence lawyers, designed to reduce the level of inputs to the efficient level through a system of fixed payments or block contracting, drive a wedge between the financial interests of the lawyer and the desire of the accused person for his lawyer to exert the maximum effort on the case.

Consider a system of legal aid in which the defence lawyer is paid from public funds for all time spent legitimately working on the case and for all expenses incurred to search for evidence relevant to the defendant's case. Under such a contract, the defence lawyer will spend time on the case up to the point where the payment received is equal to the lawyer's opportunity cost of time, i.e. the next best use of his time. This will of course be less effort than the accused would desire since the accused would wish the lawyer to exert effort so long as his or her marginal valuation is not negative. Efficiency (and thus social welfare) would require that effort be exerted up to the point where the payment equalled the marginal benefit from expending more time on the case. This is likely to result in the lawyer's effort level being greater than the socially desirable level but less than that desired by the accused. ${ }^{70}$ In the current context of plea-bargaining, this suggests that the defence lawyer is likely to spend time and effort in gathering evidence against the state's case when it would have been socially optimal to settle with a plea bargain. Thus, under such a remuneration system, we would expect more cases to go to trial or at least to continue to the day of the trial (i.e. result in cracked trials).

Under these circumstances, criminal legal aid expenditure is likely to be higher than socially desirable and largely determined by supplier driven decisions. This will lead to a desire by governments to reduce such expenditure (as in the separate jurisdictions

69 See T. Goriely, 'Legal Aid Delivery Systems: Which Value for Money in Mass Case Work? A Summary of International Experience', Lord Chancellor's Department Research Series 10/97 (1997) (socalled judicare systems such as the Criminal Defence Service in England \& Wales operated by the Government's Legal Services Commission and criminal legal aid scheme operated by the Scottish Legal Aid Board).

70 This of course assumes that a socially desirable level of effort (whatever that level might be) exists and that the lawyer's opportunity cost is no higher than the rate being paid for legal aid work. This assumption is plausible where specialisation in criminal work takes place since this is mostly legally aided. Thus the market rate for civil work (particularly non-legally aided) is not attainable by criminal law specialists. 
within the United Kingdom ${ }^{71}$ ). In order to control public expenditure, governments are likely to prefer to move to a remuneration system which reduces the incentive for lawyers to over-supply effort. ${ }^{72}$ This may be achieved by using fixed ${ }^{73}$ or standard payments ${ }^{74}$ per case or a block contracting ${ }^{75}$ system. A problem with each of these systems is that, while they substantially reduce the agency problem between the lawyer and the funding entity, they exacerbate the agency problem between lawyer and accused. By, essentially, paying a fixed fee for each case or block of cases, there is an incentive for the lawyer to reduce effort on individual cases to the minimum necessary to satisfy any externally set quality standard. Given the difficulty of externally monitoring the necessary lawyer effort, it is likely that a degree of chiselling on the amount of effort used is possible. One form of this which is pertinent to plea-bargaining is that the fixed payment may encourage the defence lawyer to advise acceptance of a plea bargain at an earlier stage than might be desirable from the accused's perspective or than is socially optimal. Whilst this might, ceteris paribus, reduce the number of cracked trials, thus reducing inconvenience to cited witnesses, and making more efficient use of court and judicial time, it works against the client's interests and may result in adverse consequences in terms of verdicts and sentences.

A recent study of the impact of changing the remuneration system for defence lawyers in Scotland for summary cases provides evidence which is consistent with such behaviour. ${ }^{76}$ A system of payment for work done in defending clients in the Sheriff summary courts

71 For further economically-motivated discussion on this, see the works cited at footnote 67 above. It should be noted that a significant difference between the policy discussions in Scotland on the one hand and those in England \& Wales on the other is that the former focussed on criminal legal aid while the latter examined civil legal aid. In Scotland during the 1990's over $60 \%$ of legal aid expenditure was for criminal cases, while in England \& Wales that proportion went on civil legal aid. See Stephen, 'Reform of Legal Aid in Scotland'. Indeed in Scotland during the 1990's, 32\% of all legal aid expenditure (civil and criminal) went on cracked trials in the Sheriff Courts.

72 Again, the assumption is that there is an efficient level of effort socially desirable (whatever the level might be).

73 Fixed payments for cases under summary jurisdiction were introduced in Scotland in 1999 where a fixed payment was paid for all work up to and including the first 30 minutes of any trial. This payment is $£ 500$ in Sheriff summary courts and stipendiary magistrates' courts and $£ 300$ in district court. Additional payments are made for each subsequent day of the trial. See further Stephen and Tata, 'Impact of the Introduction of Fixed Payments into Summary Legal Aid'.

74 Standard payments were introduced for cases in the magistrate court in England \& Wales in 1993. See generally Gray, Fenn and Rickman, 'An Empirical Analysis of Standard Fees in Magistrates' Court Criminal Cases'.

75 Block contracting systems have been introduced in England \& Wales for many categories of legal aid. See among others, E. Cape and R. Moorhead, 'Demand Induced Supply? Identifying Cost Drivers in Criminal Defence Work', A Report to the Legal Services Commission (2005). See also A. Dnes and N. Rickman, 'Contracts for Legal Aid: A Critical Discussion of Government Proposals,' 5 Eur. J. of L. and Ec. 247 (1998) (on the incentive for lawyers to chisel on quality under such systems).

76 See e.g. Stephen and Tata, 'Impact of the Introduction of Fixed Payments into Summary Legal Aid'; C. Tata and F. H. Stephen, "Swings and Roundabouts': Do Changes to the Structure of Legal Aid Remuneration Make a Real Difference to Criminal Case Management and Outcomes?', 52 Criminal $L$. Rev. 722 (2006); Stephen, Fazio and Tata, 'Incentives, Criminal Defence Lawyers and Plea Bargaining'. 
and district courts (the lowest two jurisdictions in Scotland) was replaced by a system of fixed payments from April 1999. The research compared the trajectories of cases in these courts prior to the change in payment system with those after the introduction of fixed payments. Two important results were identified: (i) a reduction in the proportion of cases going to trial; and (ii) a reduction in the proportion of cases where a guilty plea was entered. ${ }^{77}$ This had the effect of increasing both the proportion of cases terminating at the pre-trial hearing ${ }^{78}$ and the proportion of cracked trials. Both of these effects increase the likelihood that cases terminated after an attempt to plea bargain. Interviews with defence lawyers also revealed that after the introduction of fixed payments it was less common for defence lawyers to interview prosecution witness prior to the trial, ${ }^{79}$ since the cost of doing so was now covered by the fixed payment whereas it had been a billable cost under the previous system. Such an effect is consistent with either an increase or a decrease in plea-bargaining but nevertheless shows that plea-bargaining is influenced by the nature of the defence lawyer remuneration contract. The net increase in cracked trials probably represents an increase in plea bargains. This research could not determine which level of lawyer effort was optimal but nevertheless indicates that it changed with the payment system suggesting that the effort put into the underlying plea-bargaining process is sensitive to payment system.

Given that payments for legally-aided work are lower than rates for privately funded work, there is adverse selection with respect to quality of lawyers. ${ }^{80}$ Usually remuneration is fixed and not based on performance; therefore moral hazard is quite likely. Even when contracting with lawyers is for block services rather than case-by-case, management of individual cases will be likely to minimize effort disutility for the lawyer rather than the defendant's probability of acquittal. This problem can only worsen if, as some research has concluded, most defence lawyers develop an expectation that the case will end in a guilty plea, and become inclined to presume guilt. ${ }^{81}$

77 The change in remuneration system was found to be associated with an increase in the proportion of not guilty pleas because legal aid is not given in Scotland where a guilty plea is entered at the pleading diet. The inference drawn from the data is that the reduction in average income per case associated with the change in remuneration system induced lawyers to undertake more cases. There was a corresponding increase in the ratio of legally aided cases to total cases in these courts after the change in payment system.

78 Known in Scottish summary criminal procedure as the Intermediate Diet.

79 A procedure known in Scotland as precognizing witnesses. During the period covered in this research there was no system of pre-trial disclosure of evidence in Scotland.

80 The problem we refer to here is based on a comparison of rates paid by legal aid and by private clients. This situation is mitigated, as in the case of the UK, when there is little or no privately funded criminal defence work. Nevertheless, it is possible that some quality sorting takes place at the beginning of legal careers, with the better graduates going into the more profitable legal areas.

81 In the United States, budgetary limitations have tremendously impacted upon the salaries for the lawyers in public funded legal services. The problem most evident by these budgetary constraints is the lawyer shortages found in public legal work, which leads directly to very high caseloads for those lawyers working not-for-profit. There is evidence that the caseload for a lawyer in legal aid surpasses the limit to the number of persons a lawyer can competently represent generally, thus affecting the 


\section{Public Defenders}

A system of public defenders has the usual agency costs of a state bureaucracy. Given that salaries are lower than in law firms, but job security is higher, most public defenders are quite likely to be more risk averse than lawyers in law firms. Therefore, they are more likely to prefer safe strategies in criminal litigation, and plea-bargaining is one of them. ${ }^{82}$

Public defenders, unlike private lawyers, are salaried lawyers whose income does not depend upon the amount of time devoted to individual cases or the methods by which cases are resolved. ${ }^{83}$ As a result, public defenders enter guilty pleas for their clients more often than private lawyers. ${ }^{84}$ Therefore, low salaries and heavy caseloads make public legal representation for indigent defendants less effective.

Moreover, it is not only remuneration that is fixed, but also promotions and annual budget are usually based on seniority rather than performance.$^{85}$ Moral hazard problems therefore arise. There is yet another important problem: public defenders and prosecutors play a repeated game that could easily generate behavioural norms that favour collusion between the prosecutor and the public defender at the expense of the defendant. ${ }^{86}$

A review ${ }^{87}$ of legal aid delivery systems has discussed the experiences of the use of public defenders in a number of English speaking jurisdictions. It reports research that suggests that in Australia public defenders are cheaper than publicly funded independent

quality of their work. See S. E. Mounts, 'Public Defender Programs, Professional Responsibility, and Competent Representation', Wisconsin L. Rev. 473 (1982).

There could be a countervailing factor to be considered. Public defenders have considerably more job security than private lawyers and therefore they have less at stake. Private lawyers usually have their reputation and finances at stake if they take risky paths.

83 See Alschuler, 'The Defense Lawyer's Role in Plea-Bargaining'.

$84 \quad$ Ibid.

85 Note that where performance is evaluated in such a bureaucratic system the number of cases dealt with is likely to be a performance indicator. This is likely to encourage plea bargaining to settle cases before trial. In other words the incentives become very similar to those of a private defence lawyer remunerated through fixed payments or block contracts. See e.g. Stephen, 'Reform of Legal Aid in Scotland', 38-39.

Clearly generating behavioral norms that favor collusion between prosecutor and public defender is not always bad for the defendant. Certain established norms could increase efficiency (in both time and money) in the plea bargaining process, which will ultimately benefit the defendant. Ethics plays an important role in that respect. In the United States, the American Bar Association rules on professional responsibility guard against collusion between prosecutor and defence lawyer at the expense of defendant. See American Bar Association Model Rules of Professional Conduct, Rule 1.2 (a lawyer shall abide by a client's decisions concerning the objectives of representation and, as required by Rule 1.4, shall consult with the client as to the means by which they are to be pursued. A lawyer may take such action on behalf of the client as is impliedly authorized to carry out the representation. A lawyer shall abide by a client's decision whether to settle a matter. In a criminal case, the lawyer shall abide by the client's decision, after consultation with the lawyer, as to a plea to be entered, whether to waive jury trial and whether the client will testify).

87 See Goriely, 'Legal Aid Delivery Systems: Which Value for Money in Mass Case Work? A Summary of International Experience'. 
defence lawyers because they have an incentive to get through as many cases as possible. The evidence from Canada suggests that public defenders enter more guilty pleas, spend more time in plea and sentence bargaining with prosecutors but that their clients were no more likely to be found guilty and were less likely to face prison sentences. The review concludes that although Australian public defenders spend less time on cases, evidence is required on whether this is because they handle the easy cases, provide worse service, or are more efficient.

A very detailed research study ${ }^{88}$ on a pilot public defence solicitors' office in Scotland has produced comparative evidence on relative performance, including outcomes, with private defence solicitors funded through legal aid. The study reveals that clients (i.e. the accused) defended by the public defender were less likely to be satisfied and were less likely to voluntarily use the same defence lawyer again than the legally-aided clients of private lawyers. ${ }^{89}$ The study also found that clients of public defenders were more likely to have their case concluded before the day of trial (65\%) than those of private (legallyaided) lawyers (59\%). However, when account is taken of case characteristics (including the type of crime) the difference was even greater ( $71 \%$ vs. $59 \%)$ and significant at the $1 \%$ level of significance. The inference that public defenders' cases were more likely to conclude early probably explains why the research found that there was a small but significantly higher probability of the accused being found guilty when defended by the public defender. ${ }^{90}$ Overall, this evidence suggests that public defenders are more likely to be involved in concluding a plea bargain that could be against their client's interest. ${ }^{91}$

Public defenders, because of their bureaucratic context, may have less incentive to innovate than private solicitors financed through fixed legal aid payments. At least in UK and Commonwealth jurisdictions, a career pattern is likely to emerge of public defenders alternating between the public defence and prosecution services. This is likely to further exacerbate the lack of trust in public defenders displayed by clients in the Scottish study discussed above.92

88 T. Goriely et al., The Public Defence Solicitors' Office in Edinburgh: An Independent Evaluation (Scottish Executive Central Research Unit, 2001).

89 Ibid., 194.

$90 \quad$ Ibid., 4, 105.

91 Taking the client's primary interest to be non-conviction. Obviously a more lenient sentence is an objective once a conviction is certain.

92 For example, in the United States, many indigent defendants are suspicious of, and even hostile towards, their defenders as a result of the disparity in payment for public defenders versus private lawyers. Indigent defendants often refer to their public defenders as 'dump trucks', which is a term that derives from the defendant's belief that defenders are not interested in giving a vigorous defence, but rather seek only to 'dump' them as quickly as possible. Such sentiment sparked a series of courtroom attacks on public defenders by their clients. When confronted with inadequate representation, and with a judge unwilling to appoint a private lawyer, some indigent defendants believe that the best way to get rid of their public defenders has been to physically assault them in open court. See S. O'Brien, S. Pheterson, M. Wright and C. Hostica, 'The Criminal Lawyer: The Defendant's Perspective', 5 Am. J. of Criminal L. 283 (1977); P. B. Wice and P. Suwak, 'Current Realities of Public Defender Programs: A 


\section{Efficient Solutions}

From our discussion it is clear that designing an efficient system for state-funded or state-provided defence lawyers is not an easy task. The first binding constraint is that performance measures are difficult to construct, and it is well-known from incentive theory that bad measures might actually create more problems. Notably, if we increase pay to those lawyers who are successful in defending their clients (to mitigate moral hazard), we might induce a self-selection of cases based on the merit as perceived in early stages (difficult or perceived lost causes would not find an eager or motivated defender who would have an incentive to engage in early plea-bargaining to cut losses). The reason for this problem is that measuring success in a system that has variable sentences for a given crime and in which the charges can be varied by the process of plea bargaining is conceptually difficult.

The second important constraint is that of how to introduce market-related instruments (in order to mitigate or solve adverse selection) into a system that has serious problems of asymmetric information, complexity and very little financial leverage on the side of the client (the defendant). A system of fixed payments with freedom to choose the particular supplier is a first approximation to an ideal voucher system but it still suffers from moral hazard except for repeat players, but repeat players are likely to be better informed on the nature of the plea bargain anyway (although experience is not necessarily synonymous with learning in this context).

Although different countries have engaged in notably different solutions to solve these two constraints (reforms of legal aid in criminal procedure have been quite common in Europe recently), we can at most hope for second-best solutions. We should also be quite careful in introducing objective performance measures and pay-for-performance in defence counselling in the absence of a strong analytical understanding of complexity in the criminal justice system. Given the institutional specificities of the criminal justice system (where market incentives are not universal), it is also important to assess comprehensively the transplantation of performance measures in defence counselling.

\section{THE PROSECUTOR'S PERSPECTIVE}

The role of the prosecutor in plea-bargaining depends very much on the understanding of the nature of the accuser in criminal law. Tort litigation, for example, simply aims at gaining compensation for some wrongdoing (thus assuring an efficient deterrence of accidents). We could say that the prosecutor aims at obtaining a conviction in such a way that the criminal compensates society for his crimes (hence achieving an efficient deterrence of crime). Such an approach would make the prosecutor a kind of plaintiff's

National Survey and Analysis', 10 Criminal Law Bulletin 161 (1974); J. Kirsch, 'Public Defenders', New West Magazine (7May 1979), 52. 
lawyer in criminal cases, an interpretation that several scholars seem to have of the role of the prosecutor in adversarial systems. ${ }^{93}$ For reasons that are beyond the scope of this article, but have been discussed within the Law and Economics literature, ${ }^{94}$ the plaintiff in criminal cases is society and not the direct victim. ${ }^{95}$ Therefore, for the present authors, the prosecutor is best characterized as a kind of lawyer who seeks the most efficient punishment in the interests of society. ${ }^{96}$ That is, the economic model of the 'efficient prosecutor'. The prosecutor is therefore the agent of society, with an aggregate perspective of the criminal justice system, whereas lawyers usually have the perspective of an individual case. How then are the interests of the agent to be aligned with those of the principal (society)?

Economists have recognized that it is not obvious why prosecutors maximize social welfare since there is no obvious high-powered contract between them and society. Some scholars argue that if prosecutors do not maximize social welfare, they will be sacked or will not be re-elected (where that is possible, i.e. in the U.S.). For example, in the United States, the tremendous power exerted by criminal prosecutors is counterbalanced by sentencing guidelines, the supervisory powers doctrine, the doctrine of separation of powers, professional discipline, and the political process. ${ }^{97}$ These mechanisms help lower agency costs between the prosecutors and society. In a sense, contrary to the typical short-term relationship between defendant and his lawyer, the prosecutor has a longterm relationship with society (her entire career) and hence there is a repeated game. Badly behaved prosecutors are likely to be punished at some point, and this should be enough to align the general interests of society with those of the prosecutor. And so the 'efficient prosecutor' is born. Notice also that once one accepts the 'efficient prosecutor' it only makes sense to allow her to have complete discretion. ${ }^{98}$

93 Boari and Fiorentini, 'An Economic Analysis of Plea Bargaining' (it is an immediate problem with such interpretation in inquisitorial systems). See also B. Gershman, 'The Prosecutor's Dilemma: Bargains and Punishments', 14 Georgetown J. of Legal Ethics 309 (2001); L. Griffin, 'The Prudent Prosecutor', 14 Georgetown J. of Legal Ethics 259 (2001).

94 See Bowles, Faure and Garoupa, "The Scope of Criminal Law and Criminal Sanctions: An Economic Analysis and Policy Implications'.

95 See R. Pinto, 'The Public Interest and Private Financing of Criminal Prosecutions', 77 Washington Uni. L. Q. 1343 (1999).

96 By no means is the pursuit of punishment the only function of prosecution, but that only assists our critique that the model of the 'efficient prosecutor' has serious problems.

97 A. W. Dunahoe, 'Revisiting the Cost-Benefit Calculus of the Misbehaving Prosecutor: Deterrence Economics and Transitory Prosecutors', 61 N.Y.U. Annual Survey of Am. L. 45 (2005).

98 Easterbrook, 'Criminal Procedure as a Market System' (this is the essence of Easterbrook's argument for the 'efficient prosecutor'. And yet the same line of reasoning is usually rejected by economists for the 'efficient legislator' or the 'efficient government'. Easterbrook argues that prosecutorial discretion is efficient because, inter alia, the prosecutor faces incentives to behave in the public interest which other 'administrators' do not. Clearly he has in mind a US style prosecutor rather than a UK or continental European career prosecutor in a civil service post. He argues that judges, because of security of tenure, do not have the same incentive to behave efficiently. As the discussion in the text below suggests, we challenge this logic). See also D. Bjerk, 'Making the Crime Fit the Penalty: The Role of Prosecutorial 
We take the view that there are several reasons to think that agency costs between society and prosecutor are usually quite high. Institutional arrangements in place, even direct elections, do not guarantee that 'inefficient prosecutors' are punished, and hence private interests might prevail over the maximization of social welfare. Those who monitor prosecutorial behaviour - either the electorate that votes every four years or the bureaucratic bodies that prevail in most countries - have their own agenda that is usually not social welfare maximizing. Moreover, we are faced with the usual problem of specialization versus capture. The larger and less specialized the monitoring body is (e.g., the electorate), the less they are able to properly evaluate the decisions taken by the prosecutors. The smaller and more specialized the monitoring body (e.g., a supervisory body composed of senior and former prosecutors), the more likely it is to be captured.

Once we recognize that prosecutors are quite unconstrained by a powerful monitoring body that assures efficient selection of cases and allocation of effort, two important questions arise: the preferences or goals of the prosecutors; and how certain constraints on prosecutorial decision-making (mandatory prosecution, prosecutorial guidelines, judicial scrutiny of prosecutorial decisions) are actually weak substitutes for effective monitoring. It is clear that any kind of constraint on prosecutors only makes sense if we think that the 'efficient prosecutor' does not exist. We should emphasize that the choice of cases by the prosecutor does not guarantee efficient deterrence of crime and the maximization of external effects of going to trial (further development of the law or jurisprudence and testing of doctrines) when the goals are different from social welfare. ${ }^{99}$

The economic theory of prosecutors' goals is divided in two branches. One branch, the American-oriented branch, proposes that prosecutors want to maximize convictions or severity of sentences (there is an ongoing debate here). ${ }^{100}$ The most common argument is that the electorate, in general, and politicians, in particular, tend to evaluate success

Discretion under Mandatory Minimum Sentencing', 48 J. of L. and Ec. 591 (2005); J. Bowers, 'Grassroots Plea Bargaining', 91 Marquette L. Rev. 85 (2007) (looking at how interaction with the police constrains the prosecutors); R. D. Covey, 'Fixed Justice: Reforming Plea Bargaining with Plea-Based Ceilings', 82 Tulane L. Rev. 1237 (2007) (urging abandoning constraints on prosecutors' discretion and instead preventing courts from imposing harsh sentences).

But see A. Burke, 'Prosecutorial Passion, Cognitive Bias, and Plea Bargaining', 91 Marquette L. Rev.183 (2007) (when prosecutors face significant biases that impede them from achieving social welfare maximization).

See e.g. C. Albonetti, 'Prosecutorial Discretion: The Effects of Uncertainty', 21 L. and Society Rev. 291 (1987) (showing the decision to prosecute aims at avoiding uncertainty); E. Glaeser, D. Kessler, and A. Piehl, 'What do Prosecutors Maximize? An Analysis of the Federalization of Drug Crimes', 2 Am. L. and Ec. Rev. 259 (2000); G. Huber and G. Sanford, 'Information, Evaluation, and the Electoral Incentives of Criminal Prosecutors', 46 Am. J. of Political Science 334 (2002); R. Boylan and C. Long, 'Salaries, Plea Rates, and the Career Objectives of Federal Prosecutors', 48 J. of L. and Ec. 627 (2005); R. Boylan, 'What do Prosecutors Maximize? Evidence from the Careers of US Lawyers', 7 Am. L. and Ec. Rev. 379 (2005); M. Raghav, M. Ramseyer, and E. Rasmusen, 'Convictions versus Conviction Rates: The Prosecutor's Choice,' Harvard Law School mimeograph (2006); R. F. Wright and R. L. Engen, 'Charge Movement and Theories of Prosecutor', 91 Marquette L. Rev. 9 (2007). 
by the number of convictions obtained or the severity of sentences obtained in court. If so, plea-bargaining would be used to get rid of the weak cases and only strong cases would go to trial to secure spectacular sentences. Notice that the determination of weak and strong cases is from the viewpoint of the prosecutor (which, generally, is to boost conviction rates or secure severe sentences), and not from a social-welfare point of view (which states that strong and serious cases are not synonymous).

The second branch, more European-oriented, looks at prosecutors as a bureaucracy where seniority is the most common criteria for promotion. ${ }^{101}$ Incentives are for minimization of effort subject to a minimum performance. We have all the usual problems of low-powered contracts. Plea-bargaining will empower a very much unmotivated bureaucracy and is potentially used to get rid of the most demanding cases in terms of effort. Also, in the European system, prosecutors are likely to be more risk-averse than the average lawyer since they prefer job security over higher salaries in law firms. Again, such preferences support the use of plea-bargaining. ${ }^{102}$

The efficiency of plea-bargaining could be seriously compromised when prosecutors do not maximize social-welfare. Although there is a tendency to think that inefficient prosecutors' are closer to the European model than the American model, we should be careful. First, obtaining severer sanctions at the expense of low rates of conviction is not necessarily efficient (on average, we increase the severity but reduce the probability of punishment; the overall effect is quite ambiguous). Second, precisely because prosecutors in inquisitorial systems such as France and Italy are essentially bureaucrats, their powers are more limited; however, in adversarial systems, prosecutors have more latitude, which is quite problematic if their goals are not sufficiently aligned with those of society.

\section{Mandatory versus selective prosecution}

Whereas common law countries have selective prosecution systems, civil law countries usually have mandatory prosecution (usually subject to the opportunity principle as a result of which the prosecutor has some degree of discretion). Obviously, the 'efficient prosecutor' should operate in a system of selective prosecution in order to implement successful screening. Plea-bargaining is a process that induces such an outcome. However, as we move away from the 'efficient prosecutor', the selection of cases is less likely to be an appropriate focus, and mandatory prosecution starts making sense. The

101 See e.g. Boari and Fiorentini, 'An Economic Analysis of Plea Bargaining'; S. Voigt, L. Feld, and A. van Aaken, 'Power over Prosecutors Corrupts Politicians: Cross Country Evidence Using a New Indicator', Marburg University mimeograph (2006).

102 Notice here how the introduction of performance measures and eventual pay for performance in a bureaucracy such as the Crown Prosecution Service will create serious difficulties given the risk-averse profile of incumbent prosecutors. Also, there is no clear understanding in economics of what the performance measures for prosecutors should look like. Unfortunately, workload measures as usually considered by governments are quite problematic. They need to be tempered by complexity, but there are serious difficulties in modelling complexity quantitatively. 
problem with mandatory prosecution is not the lack of screening, but the allocating of the prosecutor's effort across the volume of cases. In a mandatory prosecution system, not only can shirking be a serious problem but workload could also become very grave. Therefore, plea-bargaining could be a useful mechanism not for the screening of cases but in improving the allocation of effort and in solving congestion in criminal trials.

\section{Wealthy defendants}

One of the major arguments we have discussed is the existence of serious agency costs between defendants and defence lawyers due to limited wealth (the judgment-proof dilemma). However, with corporate and wealthy defendants, the opposite problem arises. Their lawyers are well paid and agency costs should be minimal on the part of the defendant. The source of inefficiency for plea-bargaining comes instead from the fact that prosecutors are underpaid. They suffer from a typical 'revolving-door' phenomenon, as with industry regulators. ${ }^{103}$ Hence, they might promote very low penalties in exchange for a potential position of well-paid legal consultant. They will also actively engage in avoiding judicial review. ${ }^{104}$ Limitations on the kind of jobs retired prosecutors may therefore take make sense in this context; indeed, a specialized unit within the prosecutorial body to prosecute corporations with high-powered contracts (although in transaction cost economics the usual cost of specialization is precisely capture) may be worth considering. ${ }^{105}$

In summary, plea bargaining may be seen as a transaction arrived at by two agents whose interests are not perfectly aligned with those of their principals. ${ }^{106}$ On the other hand, it could be that rather than discussing plea-bargaining, we should be looking at the appropriate reform of criminal procedure in order to mitigate the problems we have encountered if plea-bargaining is to be appropriately implemented. ${ }^{107}$

\section{E. THIRD PARTY EFFECTS}

One of the major reasons why some actions are crimes and not torts is precisely because there are third-party effects. Hence, plea-bargaining as a contract between two parties is potentially inefficient since it fails to internalize third-party effects (once we reject the 'efficient prosecutor' model). A significant third party affected by the plea bargain

103 See L. Ribstein, 'Perils of Criminalizing Agency Costs', 2 J. of Business and Technology L. 2 (2007).

104 See B. L. Garret, 'Structural Reform Prosecution', 93 Virginia L. Rev. 853 (2007).

105 These problems have been analysed in the economic literature of regulation and the typical solutions proposed there should be easily carried over to the context of criminal prosecutors.

106 An alternative conceptualisation is that it is a bargain that has an external effect on parties nominally but not directly involved in the bargain.

107 See T. Sandefur, 'In Defense of Plea-Bargaining', 26 Regulation 28 (2003); contra T. Lynch, 'The Case against Plea-Bargaining', 26 Regulation 24 (2003) (a legal policy example is the current discussion in France in the aftermath of the l'affaire d'Outreau). 
is the victim of the crime. ${ }^{108}$ Although they have a direct interest in the outcome of the criminal trial, their position is not formally recognized by common law. ${ }^{109}$

Plea-bargaining is usually understood as causing secondary victimization because it is frustrating for victims (although in some cases it reduces the anxiety of a trial). Many victims are motivated by retribution or some other personal goal that is quite distinct from what economists perceive to be the common good (general deterrence). It is not the case that the preferences of the victims should be neglected in welfare economics, but they must be balanced against other social objectives. In plea-bargaining, it should not be different. The preferences of the victims should be recognized explicitly, as they are in an appropriate social-welfare analysis (e.g., the prosecutor should allow the victims to formally express their views on the matter; the victims should be heard by the judge if there is judicial scrutiny of the agreement). Nevertheless, it seems to us that it would be a serious mistake to empower victims with a veto right over plea-bargaining. This would mean that if a prosecutor and a defendant wish to make an agreement, they would have to do it in such a way that it satisfies the wishes of the victim. The problem is that the victim has no similar influence over the sentencing process in trial. Hence, many potentially efficient bargains (to say nothing of just outcomes) would fail because both prosecutor and defendant might prefer a risky and costly trial outcome over a deal that satisfies the victim. Notice that our prediction is that rather than seeing victims frequently exercising their veto rights, we would most likely observe a reduction of plea agreements in the first place.

It could be argued that without a veto, victims would be powerless to influence the prosecutor even if guidelines recommend that the interests of the victims should be taken into account (as is the case in England \& Wales, unlike the United States). Our view is that such observation justifies judicial scrutiny. We certainly take the view that the judge, and not the prosecutor, in an adversarial and discretionary system, is the best player to appraise the interests of the victims alongside other social concerns. But by no means do we want to give the impression that the judge's goals are perfectly aligned with

108 In theory, victims can prosecute most offences as tort wrongdoings, but this is little observed. The reason is that most victims lack the appropriate resources and legal powers to do so. In fact, this is an argument for why offences are punished by criminal law and not tort law: the police and public authorities have economies of scale and of scope in discovery and production of evidence. This is also true in the United States, as long as the victims meet certain statutory requirements for the specific tort alleged.

109 Recent statutory changes in England \& Wales have recognized the victim's position. The current guidelines and the Code for Crown Prosecutors require the police and the Crown Prosecution Service to take into account the wishes and interests of victims. Similar statutory guidelines exist in other jurisdictions. For example, in Israel, according to the Rights for Felony Offended Law 2001, a person who has suffered a sex or serious violent crime has to be notified of a plea-bargaining deal and has the right to express his/her opinion beforehand unless the prosecutor decides that it may substantially harm the process. For the United States; see M. O'Hear, 'Plea Bargaining and Victims: From Consultation to Guidelines', 91 Marquette L. Rev. 323 (2007) (the wishes and interests of the victims may be informally taken into account by prosecutors, however the law does not require that this happen). 
the interests of the victims or those of society in general. There are agency problems also on the side of the judiciary. However, it seems to us that the judge is the player in the nexus of relationships that we have established best positioned to take into consideration the interests of third parties, and victims in particular, as we explain in the following section. ${ }^{110}$

\section{F. JUDICIAL SCRUTINY}

Judicial scrutiny of plea-bargaining has been recognized lately by economists as a way to mitigate the misalignment of goals between the prosecutor and the rest of the community. It seems to us that judicial scrutiny is also probably a way to address this problem, albeit imperfectly, but there are not that many more available to detect any major misalignment between the defence lawyer and the accused. We further understand the judge as being in a position to take the interests of the victim into account in much in the same way as the judge is supposed to appraise the interests of children in divorce law, and hence, has the ability to reject a custody agreement between mother and father if the children's interests are not best served.

We do not neglect the effects that repeated interactions between judges, prosecutors and defence counsellors may have in the emergence of a common culture that undermines the interests of the defendant. In fact, below we argue that ex ante judicial scrutiny will naturally lead to such an outcome (it should be even more likely in civil law countries, such as France and Italy, where prosecutors are a branch of the judiciary). However, the problem is not due to plea-bargaining, or even specific procedural rules, but to the incentives put in place for the different professions; the same kind of problem shows up even if plea-bargaining is not allowed. ${ }^{111}$ Therefore, although we take a positive view of judicial scrutiny, by no means do we believe it completely solves the misalignment of interests we detailed above. ${ }^{112}$

If we take this view on the role of judicial scrutiny, then it only makes sense to make it mandatory and active. Mandatory means that all plea-bargaining contracts or recommendations should be confirmed by a judge, as a purely selective (that is, there is judicial scrutiny if and only if at least one party requests it) system does not make sense (if both sides agree to the contract, why should one side request a judicial review?). Active means that the judge should be empowered to enquire about the full scope of

110 See Empirical Measures of Judicial Performance Symposium, 32 Florida State Uni. L. Rev. (2005) (the debate on how to evaluate and how to pay for performance in the judiciary has been the subject of a recent symposium).

111 The use of juries in criminal trials can mitigate the problem.

112 Contra R. Klein, 'Due Process Denied: Judicial Coercion in the Plea-Bargaining, 32 Hofstra L. Rev. 1349 (2004); N. King, 'Judicial Oversight of Negotiated Sentences in a World of Bargained Punishment', 58 Stanford L. Rev. 293 (2005); S. Klein, 'Enhancing the Judicial Role in Criminal Plea and Sentence Bargaining', 84 Texas L. Rev. 2023 (2006); Covey, 'Fixed Justice: Reforming Plea Bargaining with PleaBased Ceilings'. 
the agreement and unilaterally reject it. The rationale would be that such an increase of power to the judges would discipline prosecutors and lawyers ex ante to strike a good deal (on the basis of the evidence). Obviously, we can temper this extensive and costly work for judges; plea-bargaining for minor offences with limited scope (a fixed reduction of a not very severe sentence in return for a guilty plea) should not be subjected to mandatory and active judicial scrutiny, but plea-bargaining for serious offences or where the scope is complex (including charges, disclosed facts, and profile of sentencing) would be. ${ }^{113}$

By construction, our argument points out that a more constrained judiciary will increase the power of the prosecutor and hinder the efficiency of plea-bargaining. ${ }^{114}$ Such a conclusion is based on our rejection of the 'efficient prosecutor' model. We also understand that those scholars who believe in the 'efficient prosecutor' can only welcome any constraints on judicial intervention. ${ }^{115}$

Our main conclusion is that, although judicial scrutiny will increase the costs of pleabargaining and create delays, the advantages it offers are quite important. ${ }^{116}$ These costs should not be underestimated when determining the offence with which the accused is to be charged is the prerogative of the prosecutor. We also recognize that victims should play an important role, but we would not consider granting veto rights to victims; rather, the judiciary should be empowered to take the interests of the victims into consideration. ${ }^{117}$

\section{Judicial intervention after plea-bargaining}

The model we have in mind is that of ex post judicial scrutiny of plea-bargaining, that is, judges only intervene after the bargain has been concluded by the parties. Their role would be essentially to unilaterally reject the parties' sentence recommendation. The consequences of the judicial rejection can be threefold: (i) invite the parties to renegotiate a sentence; (ii) conduct a trial; (iii) impose a harsher sentence (given that a guilty-plea has been entered, although rules on self incrimination could be used to limit this possibility). We take the view that the full menu should be available for judges in order to improve plea-bargaining.

113 See O. Gazal-Ayal, 'Partial Ban on Plea Bargains', 27 Cardozo L. Rev. 2295 (2006) (on partial versus total bans of plea-bargaining).

114 See P. Secunda, 'Cleaning up the Chicken Coop of Sentencing Uniformity: Guiding the Discretion of Federal Prosecutors through the Use of the Model Rules of Professional Conduct', $34 \mathrm{Am}$. Criminal L. Rev. 1267 (1997).

115 Easterbrook, 'Criminal Procedure as a Market System'.

116 Whereas in contrast, for example, costs and delays seem to us an important argument against judicial review of a prosecutor's decision to drop a case (a principle upheld in Anglo-American criminal procedure). Obviously the decision not to prosecute in many cases hurts the victim and causes secondary victimization, but this concern can be easily addressed by designing rules of mandatory prosecution for certain types of crime.

11 Although judges might generally think that sentences agreed by plea-bargaining are too low, they would not veto systematically to the point at which plea-bargaining is undermined because that would increase their workload severely. 
The option of conducting a trial is important when the interests of the defendant's lawyer are significantly misaligned with those of the defendant since it will be a binding constraint. However, given the caseload pressure, it would be naïve to think that judges would use this possibility in most cases. Hence, we would think that it is important to have that possibility for certain cases, but would not expect too much use of such an instrumentality.

Assuming that judges want to minimize time spent on a case and therefore wish to avoid trial once they are reassured of their influence in sentencing, it seems to us that the third solution is the more likely to occur and also possibly the more appropriate for two reasons. First, imposing further renegotiations, or trial, increases costs for the judge, thereby creating an incentive to accept the recommendation by the parties. Second, the possibility of imposing harsher sentences will make both parties, prosecutor and defendant, assess the evidence and the strength of the case more judiciously (for example, the prosecutor can no longer fully promise a sentence in return for a plea of guilty, and the defendant faces a significant risk). Obviously, a rejection of a negotiated sentence might deter future plea-bargains, but this externality will be distributed across the judiciary in general, and will not affect the deciding judge in particular (unless a judge engages in a systematic strategy of rejecting plea bargains).

The activism of expost judicial scrutiny will depend very much on how judges perceive plea-bargaining. It is unlikely that judges will frequently reject recommendations if they do not feel negatively affected by this type of criminal procedure. If prosecutors are able to anticipate judicial behaviour, plea-bargains can be tailored to satisfy judges and rejections are unlikely to occur.

\section{Judicial intervention before plea-bargaining}

A different model would be one in which judges intervene in plea-bargaining before a negotiated solution is achieved or at the outset of the bargaining process. Ex ante judicial intervention is more likely when the prosecution cannot recommend, propose or commit to a sentence. However, the incentives for judges in an ex ante intervention are not any different from those of prosecutors, given caseload pressure. Therefore, they are interested in encouraging guilty pleas in weak cases. ${ }^{118}$ Furthermore, if judicial intervention is possible from the early stages, the judge would quite possibly replace the prosecutor as the main negotiator with the defendant, thereby diluting the adversarial nature of criminal procedure (in fact, empowering the judge with a more inquisitorial role than usual practice in common law). An important consequence of ex ante judicial

118 For example, the fact that the Turner Rules were systematically violated and not very popular across the judiciary are but just an indication that judges wanted a more active role in the negotiation over guilty pleas. 
intervention is making the judge one of the sides rather than a third-party in the contractlike negotiation. ${ }^{119}$ Therefore, we are not enthusiastic about this type of intervention.

\section{$\S 5 . \quad$ CONCLUSION}

The literature on the economics of plea-bargaining is largely over-optimistic and contrasts with legal scholarship on the topic. We have shown that part of the reason is that it still relies heavily on the 'efficient prosecutor' model, and only recently has started looking at the possible advantages of judicial scrutiny. As a consequence, the economics of plea-bargaining has largely failed to influence the debate in Europe and around the world. Further, it was unable to predict the relative failure of the system in Italy (and possibly France), although there is an ex post rationalization for this (bargaining as an inadequate solution to delays in trial rather than as a device to generate prosecutorial efficient allocation of resources).

This article proposes a new approach based on viewing the contract, which is at the heart of the plea-bargain, as being located in a wider nexus of relationships involving parties who are not directly (or effectively) represented at the bargaining table. By looking in detail at the contract between defendant and his lawyer, the role of the prosecutor, and third party effects, we have provided a richer model that is more sceptical of the efficiency of plea-bargaining. ${ }^{120}$ We also point out that a successful transplant of pleabargaining from the United States to civil law jurisdictions such as France and Italy will very much depend on a reform of criminal procedure that addresses the agency costs we have identified.

The comparative efficiency of plea-bargaining depends to a larger extent on the possibilities within a legal system of addressing the multiple principle-agent problems in criminal litigation. In particular, the principal-agent problem between the defendant and the defence councillor should be the focus of reform (for example, in terms of payment structure) before plea-bargaining can be successfully transplanted. Another comparative implication of our paper is the role of prosecution, namely the organization and performance incentives.

The main purpose of our approach is to highlight that it is not a good idea to separate plea-bargaining from a serious and comprehensive assessment of reforms in prosecution and defence counselling. In particular, a better understanding of the incentives and performance generated by the current system of remuneration and evaluation play an important role in determining the success or failure of transplanting plea-bargaining

119 See J. I. Turner, 'Judicial Participation in Plea Negotiations: A Comparative View,' 54 Am. J. of Comp. L. 199 (2006) (many jurisdictions in the United States, including the federal, expressly prohibit judges from participating in or commenting on the plea negotiations).

120 But see S. Howe, 'The Value of Plea Bargaining', 58 Oklahoma L. Rev. 599 (2005); C. O. Holdfather, 'Heuristics, Biases, and Criminal Defendants', 91 Marquette L. Rev. 249 (2007). 
into a given criminal procedure. Reformers of criminal procedure should not limit themselves to narrow definitions, but look to the general framework in which pleabargaining operates in order to design successful and effective reforms. Unfortunately, many civil law jurisdictions have transplanted plea-bargaining without such debate, and therefore the results have not been consistent with the general optimism exhibited by many legal economists. 